\title{
Cultural Differentiation and Social Integration in Complex Modern Societies Reflections on Cultural Diversity Management Strategies from a Sociological Point of View
}

\author{
Rosalia Condorelli \\ Department of Political and Social Sciences, University of Catania (ITA), Catania, Italy \\ Email: rcondor@unict.it
}

How to cite this paper: Condorelli, R. (2018). Cultural Differentiation and Social Integration in Complex Modern Societies Reflections on Cultural Diversity Management Strategies from a Sociological Point of View. Sociology Mind, 8, 249-303. https://doi.org/10.4236/sm.2018.84019

Received: July 31, 2018

Accepted: September 2, 2018

Published: September 5, 2018

Copyright $\odot 2018$ by author and Scientific Research Publishing Inc. This work is licensed under the Creative Commons Attribution International License (CC BY 4.0).

http://creativecommons.org/licenses/by/4.0/ (c) (i) Open Access

\begin{abstract}
This paper reflects on foundations of integration in our differentiated and globalized society from a sociological point of view, and links this reflection to most recent scientific acquisitions of the New Systems Theory or Complexity Science about how all systems, natural as well as social systems, work and evolve. Incorporating the sociological tradition on differentiation processes as rule of social functioning, the contemporary sociology accepted emergent, far from equilibrium (entropy), self-organization, unpredictable and surprising organizational change processes, operative closure and autopoiesis concepts, as particularly adapting concepts to represent social systems and, above all, our contemporary society characterized by an increase of complexity due to differentiation, individualization and globalization processes. In this regard, strong and permanent migratory waves, due to economic and digital globalization processes, and increasing cultural differentiation processes, have led contemporary western societies to face a serious social organizational problem: how the recognition of cultural difference and the instance of social integration can be reconciled? In this regard, the characterization of all systems as able to adapt to environmental perturbations and survive by self-organizing, balancing organization integrative constraints and emergencies, that is, far from complete differentiation, without being even minimal connection (far from equilibrium or in the edge of the chaos), can constitute a valid point of reference for sociologically reflecting, starting from here, on current integration policies of cultural differences in our complex society (pluralism, multiculturalism, interculturalism) and their implications for social integration. About it, the paper accepts the perspective of those sociological and political theories according to which, from a theoretical and em-
\end{abstract}


pirical point of view, the sufficiency of procedural foundations seems to show serious limits as integrative constraint. Therefore, the Complexity language can justify the caution with which the normative multiculturalism-which implies it-is believed that should be considered, by anchoring it to the vision of a society conceived so as to dangerously visit that range of maximum differentiation which should be avoided, being identified as the range of ungovernability. Islamic radicalism and nationalistic rejection signs in the West show that this is no a mere theoretical possibility. How to bridge this relationality deficit that normative multiculturalism seems to institute and avoid the risk of a society unable to regain order with coherence? The Complexity framework is where the entire debate must be kept. Here, the integration proposal of interculturalism can gain greater meaning, avoiding the risks of mono-culturalism, on the one hand, and social balkanization, on the other hand.

\section{Keywords}

Identity and Otherness, Complex Social Systems, Social Integration, Multiculturalism

\section{The Framework of the Problem}

This paper reflects on foundations of integration in our differentiated and globalized society from a sociological point of view, and links this reflection to most recent scientific acquisitions of the New Systems Theory or Complexity Science about how all systems, natural as well as social systems, work and evolve. Incorporating the sociological tradition on differentiation processes as rule of social functioning, the contemporary Sociology (i.e. Luhmann, 1984) accepted emergent far from equilibrium (entropy) self-organization, unpredictable and surprising organizational change processes, operative closure and autopoiesis concepts, such as Prigogine (Prigogine \& Nicolis, 1977; Prigogine \& Stengers, 1979) suggested for dissipative structures in Physics and Maturana \& Varela in Neuro-cognitive Sciences (1984), as particularly adapting concepts to represent social systems and, above all, our contemporary society, characterized by an increase of complexity due to differentiation and globalization processes. Accepting the Morinian definition of systems (Morin, 1977; 2008) as unitas multiplex (solidal ring or interweaving of interactions-complementary, antagonistic, concorrent relationships - such that no one exist and can be understood in isolation from the whole, proceeding by constraints and emergences, by qualitative jumps), the conception of modern society as complex society is very justified. Morphologically, the images of modern society as a network society, risk society, or uncertainty society are those that best represent the social complexification process. Worldwide circulations of goods, capital, businesses, people, ideas, cultures, mark the transformation of the world in which we live to a complex unity, 
a meta-structure that connects a dense network of cultural, political and economic relations never before seen in any other historical epoch. The idea that increase in complexity engenderates is that of a differentiated society, individualized and globalized, and interconnected society, characterized by a plurality, not linked to a place, of social spheres, networks of communication, market relations, lifestyles, signaling the decline of the nation-state (Beck, 1997), and by rapid, unexpected and profound changes in social organization, disorganization and emergent, unpredictable, surprising re-organization processes, due to scientific and technological-digital progress and to degrees of freedom conquered by individualization processes with respect to rigid institutionalized principles of social regulation of traditional order.

So, in our modern complex, individualized and democratic as well as culturally more and more differentiated societies, because of strong and permanent migratory waves due to economic and digital globalization processes, societies, cultural differentiation has led contemporary Western societies to face a serious social organizational problem involving integration, that is, to aspects of social conflict that make social integration and cohesion problematic and require solutions.

The framing of the problem is the following.

Current strong migratory waves due to globalization process have emphasized the problem of the meaning by which the concept of equality should now be understood in social contexts marked by an unprecedented state of alterity excess (Grillo, 2007, or, with another eloquent expression, of super-diversity, Vertovec, 2007), and strongly reiterated the theme of identity and ways of possible reconciliation between diversity, social integration and cohesion.

Such issues naturally lead to debate on postmodern Societies. The current local cultures expansion on a global scale and processes of new localization within different socio-cultural contexts lead to outline a postmodernity that encompass tensions due to the de-localization and re-localization, the territorial decomposition and re-composition, of social and cultural ties, now without any more boundaries of space and time. This is the basis of the identity problem. The progressive shattering of those boundaries, of those symbolic barriers from which, however, local cultures had previously received some form of protection, re-introduces the theme of the encounter/clash between different cultural identities, different universalisms characterized by different value systems and different processes of individual identity building. Western cultural universalism, with its characteristics of rationalization, liberalism and moral individualism, collides with other universalisms, such as, for example, the Islamic one, which in its most traditionalistic form accentuates largely collective and community dimensions that contribute to structuring the subjective identity perception and reality interpretation. Thus, emerges one of the peculiarities of post-modernity, which adds to tensions of modern solidarity, associated with rationalization canons and the predominance of the individual dimension of identity in respect to the col- 
lective one, a permanent tension between rationalization and individualization requirements, on the one hand, and membership needs and collective, national and religious identities claims, on the other hand. Due to the fact that our societies are becoming more and more immigration societies, the peculiar dilemma of modern societies is in finding ways to encourage and promote peaceful social relations among different cultural universes, host societies and minority groups: how to configure the relationship between alterity and identity, how to create unity from difference, promoting a peaceful coexistence and social cohesion state based on equity criteria. What integration and cohesion model should we realize? How can integration and social cohesion emerge and be maintained in a context of ever-increasing cultural differentiation? How the recognition of cultural difference and the instance of social integration can be reconciled? Different organizational change solutions have been proposed and a controversial debate has started up. Procedural foundations of integration, as normative multiculturalism wants, or moral foundations, a base, albeit minimal, of shared values between "us" and "them", as pluralism theories suggest?

This debate is very controversial.

As just said, over the last few decades, moral philosophy and political theory have proposed different approaches to these issues, depending on the emphasis on individualization or collective identification processes of identity construction. The link is immediately apparent: depending on which dimension of identity is emphasized, different modes of conceiving the bases of integration and social solidarity, different modes of recognizing rights (individual rights vs. collective rights), and, therefore, understanding the difference and the modes of inclusion and relationships with it, result (Colombo, 2002). In this sense, liberals and communitarian, already split on the question of identity, have further divided themselves over the question of relationship management between identity and alterity. In general terms, we can say that all the positions appear classifiable according to a demarcation line marked by the answer to the main problem, i.e., as Hall $(2000,2001)$ states, whether cultural differences are always and exclusively restricted to the private sphere for a universal equality of rights, according to the model of liberal-democratic pluralist inclusiveness (undifferentiated citizenship), or whether, as the most recent multiculturalist inclusion model states, cultural differences must be publicly recognized and have a place in political life according to a different meaning of the principle of equality, intended as public respect of differences.

Thus, multiculturalism, as a social inclusion and integration model (outgroup-ingroup), in other words, a normative model for regulating relationships with ethnic differences in a social context in which a preexisting, dominant culture prevails, emphasizes as its theoretical assumption, and as criterion of coexistence and social integration, the enhancement of cultural specificity, being the founding principle of individual and collective identity and, therefore, worthy of being promoted, recognized, protected, safeguarded in the public sphere against 
assimilation attempts and/or segregation and social exclusion practices.

Multiculturalism is, therefore, a theory, a doctrine of difference, and policy of difference. Emphasized in principle, the valorization of cultural specificity is resolved in a policy of recognition of special, collective rights, differentiated by group, which takes into account the specificity of individual value communities (differentiated citizenship, which extends universal citizenship, based on equal economic, social and political rights, to incorporate cultural, differentiated, group rights; Young, 1989, 1990; Taylor, 1992, Kymlicka, 1995a, 2018). On this common matrix, which rejects the individualistic conception of liberal society, overturning the liberal individualistic conception of the privatization of differences, in the name of universalistic principles of equality, in recognition of differences on a public and institutional level, two main currents of thought can be distinguished, based on the degree in which the recognition is conceptualized, resulting in more or less radical positions.

The communitarian multiculturalism emphasizes a recognition process of collective rights which confers, in a more radical way, full autonomy from mainstream (separate Institutions-Schools, Courts, Hospitals, Churches, Cemeteries...-from dominant institutions) to different ethnic and cultural communities, present in the same socio-political reality. The pluralist multiculturalism follows a liberal-democratic orientation (Zamagni, 2002), agreeing to the recognition of cultural minority group rights while, at the same time, limiting practices and traditions being contrary to liberal principles of respect for the dignity and liberty of human beings (such as polygamy or infibulation) (Kymlicka, 1995a; 1995b). Above and beyond the greater or lesser radical recognition status, collective rights represents, for both versions, the conditio sine qua non for honoring ethnic and cultural differences and is the key element for creating inclusion, social cooperation, peaceful coexistence and cohesion.

As mentioned above, the sufficiency of criteria relating to pluralistic and liberal-democratic model of relationship and communication, of social coexistence and integration, deriving from Enlightenment inspiration, comes into question. From a liberal point of view, the public-private distinction is the main virtue of liberalism, which finds the solution to religious, cultural conflicts, from which it historically originated, in the strategy of privatization and public secularism (Barry, 2001). Freedom of choice and action as a right which is recognized to the individual as such (including religious freedom), regardless of race and membership to a particular community of social practices, values and traditions, the universal equality, as a principle of guarantee of the real possibility of activation in the public sphere of individually recognized liberties and identities, and the liberal neutrality of the State with its universal citizenship, do not seem, according to multiculturalists, be sufficient to ensure full realization of identity and freedom of choice, action and participation in the political arena of those who recognize themselves in a community of traditions and values other than those constitutive of the host society's culture, nor, as a result, a peaceful social coha- 
bitation. The realization of this freedom of individual choice would only come about through public recognition of the specificity of the culture of belonging, as a cognitive reference parameter for building personal identity and for the interpretation of reality.

If, therefore, from the pluralist-liberal perspective, freedom in equality and its exercise, respecting democratic principles, are the means of ensuring the very possibility of difference, avoiding diversity can become a source of inequality and discrimination, precisely this system is a source of inequality and discrimination for the theorists of Pluralist Multiculturalism à la Kylimcka and communitarian approach à la Taylor. This is not only because equality so understood, within the framework of an individually recognized right of liberty, end up absorbing and phagocytizing differences and, de facto, not to recognize them, but also because it needs, for its public recognition and validation, the legitimacy of a criterion, that of the majority, which could disadvantage and exclude cultural minorities.

In this sense, criticism against the universalist claims of the individualistic and democratic "open society" model, based on the union of freedom-equality, is criticism against an inclusion process that would naturally lead to the disappearance of cultural differences, creating assimilationist and homogenizing risks and a poor level of social equity (on the possible integration limits of the assimilationist approach, the French example can be cited, guilty of encouraging exclusion, marginalization, social isolation of entire sectors of the population, and a general state of possible conflict,; see Murray, 2006; Silberman et al., 2007). The salad bowl seems to be the most suitable metaphor for expressing the multiculturalist idea of a social coexistence project where all differences would likely coexist, distinctly and publicly recognized, without annulling themselves or merging into a single cultural and social reality (melting pot), with greater guarantee of equity and social justice.

No doubt, this multiculturalist re-definition of coexistence rules with identity minorities has been affected by the processes of change that, from a sociological and historical point of view, have characterized the migratory phenomena, particularly referring to the behavioral model of immigrants in post-modern societies. Contemporary, sociological discussion has highlighted how the newcomers that currently reside in both Europe and North America have sociological connotations that are very different from those we were used to during the initial migrations of the nineteenth and early twentieth centuries, and how this affects the addressing of the debate on contemporary democracy. For a long time, the social action of the migrant was not directed so much to maintain differences but to attain full social and cultural integration for equal economic and political participation along with the native population. After a clean break from the country of origin, migrants of the past aimed at achieving as quickly as possible assimilation and new acculturation (Zamagni, 2002), because the opening to the customs and traditions of the new homeland represented the necessary prere- 
quisite for the economic success and social recognition (Colombo, 2002). Today, on the contrary, migrants tend to speak more and more the language of their ethnic roots, share a strong collective identity which is no longer satisfied by the freedom-equality model, of which assimilatory risks are feared. The "melting pot metaphor does not stand", Glazer wrote already in 1970 in his Beyond the Melting pot (1970), signaling in the United States the persistent resistance, throughout generations, of the cultural specificities of Latino and Afro-American minorities to be melted and amalgamated in the highly vaunted crucible of a new humanity. On the other hand, today's migrations, especially of Muslim cultural matrix, pose new problems-new challenges to Western liberal-democratic systems (especially European), and to the principles that have inspired the political foundations of social cohesion.

It is of no surprise, then, that, through these processes of change, the issue of identity and the relationship between identity and otherness has increasingly become central, in the political sphere, as well as in academic debates. Hence, is born, as said above, a new sentiment towards cultural difference, and a rebirth of policies, capable of valorizing difference through the public recognition of belonging to a group in the name of which autonomy and privileged access to social resources can be claimed.

For its part, the doctrine of multiculturalism (no matter whether communitarist or pluralist) emerges to give theoretical support to the demands of difference recognition advanced by ethnic-cultural and religious minorities, theoretically arguing the right of everyone to form their own identity not only as an individual but also as a culture (Taylor, 1992), and emphasizing the recognition not only of individual rights to freedom and life but also to other rights that do not derive from our humanity but from collective conceptions of social goods and with a local and particular character (Walzer, 1999). In fact, according to Taylor, the feeling of authenticity, the same sentiment which modern sensibility advocates, asks today to Western contemporary democracies an active commitment towards the policies of identity as an active recognition of the right to freedom to preserve and cultivate one's own cultural specificity (the proposal for a type 2 liberalism).

Adopted, thus, officially for the first time in Canada in 1971 as government policy by the Canadian Multiculturalism Act, in order to establish an equality declined on the recognition of cultural difference by affirming the value and dignity of all Canadian citizens, without distinction of racial or ethnic origins, language and religion, afterward countries like Australia, New Zealand, and, for Europe, at the beginning of the 80s, Great Britain, Denmark, the Netherlands, Norway have implemented and experimented the model of inclusion and integration based on multiculturalism, recognizing large areas of freedom for ethnic and religious communities, with the possibility of organizing oneself starting from one's own rules and customs (Glazer, 1997).

Sociological research interested in contextualizing the application, in political 
terms, of multicultural doctrine demands and in empirically evaluating their implications, offers a rather varied panorama. Referents of multicultural policies have changed over space and time. Thus, the trans-oceanic precursors of multiculturalism focused on national minorities or on indigenous groups. In fact, the referents of Taylor's theorization were the Canadian Anglophone minorities present on the French speaking territory. Nowadays, the referents, especially in Europe, have become Islamic culture minorities.

From this perspective, acknowledged again in the 2000 Runnymede Trust Report, The Future of Multi-Ethnic Britain, multicultural British orthodoxy, for example, referring more to colonial immigration minorities than to national minorities or indigenous groups as concerned the trans-oceanic precursors, ensured public recognition of ethnic and cultural differences in various institutional areas (group rights valid for legitimizing institutional autonomy in reference to schools, cemeteries, churches, courts such as the Shari'a courts), as well as through a variety of public measures such as the adaptation of school curricula, support for food codes, clothing codes (i.e., the exemption for Sikhs to wear the helmet) and organizations and consultative bodies, health prevention campaigns in multiple languages, work permits for cult practices, recognition of different matrimonial contracts, divorces and traditions related to inheritance succession, media controls to avoid offensive and discriminatory stereotyping. We can find a large variety of local civic programs, depending, from time to time, on the assumptions of what has been called radical multiculturalism or polycentric multiculturalism (Shohat \& Stam, 1994), insurgent multiculturalism (Giroux, 1994), public space multiculturalism (Vertovec, 1996), difference multiculturalism (Turner, 1993), critical multiculturalism (Foreign Policy Centre Chicago Cultural Studies Group, 1994), and weak or strong multiculturalism (Grillo, 2005).

Recently, however, if it is true, on the one hand, that the multiculturalist inclusion model reflects the social and political tensions created by an ideal of equality increasingly felt in a constrictive way, tensions that seemed no longer able to find their political synthesis in the program of integration-assimilation of the differences shared up to then by the western nation states, on the other hand it has become the subject of a heated debate on the academic and political levels.

Multiculturalist principles have had to face a hard confrontation with the Islamic cultural specificity: the migratory minorities of Islamic culture would put to the test the presuppositions of union and social communication, the promises of peaceful coexistence that justify the adoption of multiculturalist practices and policies of identity recognition. After more than thirty years, starting from the terrorist attacks in New York, Madrid and London between 2001 and 2005, the murder of Teo Van Gogh in Holland by a Dutch of Moroccan origin and the increasing radicalization of costumes and the traditions of Islamic communities indexed everywhere in Europe by a growing trend of arranged marriages, honor killings, practices of infibulation, the issue of whether multiculturalism is a valid response to guaranteeing a state of social integration and peaceful coexistence 
between cultural identities different coexisting within the borders of the same nation and with a dominant culture has strongly questioned the political and above all academic world.. The issue of whether the emphasis on ethnic roots and cultural recognition through Institutions of group rights can foster a relational nature and good communication between groups, or whether they will separate and alienate them, potentially compromising social cohesion and peace, assumes, today, in an increasingly complex migratory picture, new specificity, and requires a treatment that takes proper account of it. The most recent attacks on Brussels in 2015, in London, and in Finland, as well as in Paris, Nantes, Berlin, Spain and Austria confirm this issue's pressing social importance.

Regarding the political sphere, in recent decades, the US as well as Great Britain and other European countries, which have been at the avant guard in the practice of multiculturalism have experienced what has been termed cultural-diversity skeptical turn or, again, multiculturalism backlash (Vermeulen \& Pennix, 2000; Brubaker, 2001; Scheffer, 2001; Kundnami, 2002; Entizinger, 2003; Joppke, 2004; Grillo, 2005, 2007; McGhee, 2005, 2008; Slack, 2006; Lust, 2008; Simon \& Sala Pala, 2010; Prins \& Saharso, 2010; Hedetoft, 2010; Schönwälder, 2010). Terms like "crisis", "failure", "sunset", "retreat", "death" of multiculturalism now appear in the agenda of political discourse, shifting from the affirmation of differences to shared values.

For example, echoing the contents of the 2001 Cantle Report, following the racial unrest in several cities in Northern England, encouraging immigrant identity minorities to live separate, parallel lives without sharing national liberal values, was the effect of the multicultural toleration already denounced by David Cameron when he was British Prime Minister, and, before him, by the German Chancellor Angela Merkel. This same state of affairs has also induced the Netherlands and Denmark to rethink the possibilities of difference recognition with renewed caution.

Centrist civic integration policies (education programs that promote host country's language learning, history, traditions, liberal and democratic values; the introduction in UK of citizenship tests as well as of Gesinnungtest and of naturalization ceremonies in Germany; and the latest institutional de-radicalization programs in Denmark) are clear signs of current policy changes.

In the academic sphere, the emergence, in the current migratory picture, of dissonant effects with respect to the multicultural premises and promises of union and social peace, has become the contingent occasion to rediscuss the assumptions of normative multiculturalism. In this regard, the contemporary debate seems to be characterized by the radical divergence of positions.

On one hand, it has been pointed out that the recognition of group rights and religions in the public sphere, cannot be called into question by Islamic radicalism, and that, on the contrary, the relevance of normative multiculturalism must be reaffirmed as project of nation-remaking and constructing a new national identity and a new social cohesion, articulated around the fundamental respect 
of cultural freedom, according to a concept of equality not reduced to homologation and assimilation (Modood, 2007/2013, 2010, 2011, 2018a; Meer \& Modood, 2009, 2013; 2015; Kymlicka, 2010, 2018). According to Modood, which has presented normative multiculturalism as a form of dialogical citizenship (Modood, 2007/2013: pp. 126-128, 116-118), the error lies rather, in an conception of culture which does not recognize differences within groups, consenting to the identification of the religious identity of the Muslims sic et simpliciter with Islamic fundamentalism From Modood's perspective (Meer \& Modood, 2009; Modood, 2011, 2018a), no doubt, reviving ideological secularism would mean, on the contrary, to thwart the construction of a new multicultural national identity and, therefore, a more inclusive integration of Muslim communities-who recognize themselves as religious entities-in the democratic city, where feelings of belonging to the mainstream can bind with those belonging to the culture of origin (hyphenation).

On the other hand, some major criticisms have been advanced, to the doctrinal formulation of multiculturalism itself, highlighting potential ethical-political risks inherent in and of itself in the paradigm of group rights, always liable, from these interpretive perspectives, to invalidate the results of his, albeit in more or less variable forms, applications (Schlesinger, 1992; Touraine, 1998, 2011; Heller, 1996; Baumann, 1999; Barry, 2001; Sartori, 2000; Samir Khalil, 2001; 2007; Benhabib, 2002; Zamagni, 2002; Colombo, 2002; Tibi, 2002; Joppke, 2004; Donati, 2008; Sen, 2006a, 2006b; Maxwell et al., 2012; Malik, 2014; Guidikova, 2014; Cantle, 2012, 2015, 2016). Touraine, for example, writes; "The dream of cohabitation has gone into crisis; the extreme defense of cultural differences having finally produced unacceptable contrapositions and the rejection of others' rights" (Touraine, 2011: p. 42). Almost "everywhere" in fact, "an intransigent communitarianism, resistant to any sort of integration, would have prevailed" (ibid). From this perspective, the effects cited would be the result of, as Sen calls it, "a fallacious reasoning" (Sen, 2006b: p. 35) The main issue lies in the ways "recognition" is conceived: as an unilateral act, which goes from majority to minority (especially in the version advocated by communitarian multiculturalism or multi-communitarianism, as Wieviorka calls it, 1998a \& 1998b, 2001), rather than in terms of reciprocity, as expected in the model of pluralist-liberal inclusion and social integration, focused on the recognition of individual and non-collective rights. Following this line of reasoning, one might therefore deduce, that if the recognition policy is in crisis, the principle itself of group rights recognition seems to contain within itself the germs of its own crisis, the emphasis on ethnic roots seems to contribute to weaken the relationship between autochthonous identity and otherness, separate and isolate the different cultural communities, break up the social fabric into a multiplicity of non-communicating social worlds, or, as Sen calls it, into a pluralism of monocultures, of traditions that coexist side by side without ever meeting each other, without ever sharing anything in common (Sen, 2006a). The question, in essence, invests the very foun- 
dations of social integration and social solidarity.

On another front, gender studies have considered the impact of multiculturalism on women's rights, arguing how it can lead to tolerating traditions that discriminate against them, and ending by theorizing a multiculturalism without culture.

In short, it is therefore possible to observe a certain convergence between themes of academic debate and themes of the political agenda. Multiculturalism presents itself in a dual role. On one side, it presents itself as a possible solution to a problem, on the other hand as a problem itself; on the one hand it is appreciated for having underlined the equality of the right to difference, on the other it is assessed as a possible source of intolerance, separateness of minorities, cultural relativism, fragmentation and social conflict .And it is not surprising that in the context of these criticisms, we can now see, in terms of political and academic discourse, the conceptualization of post-multiculturalism models, which insist on the need to connect more closely social cohesion, a common sense of citizenship, shared values and national identity with the valorization of diversity in the public sphere (Vertovec, 2010). It is not a question of affirming the implicit claim that theory and political discourses of multiculturalism backlashes are causally correlated and not guided by specific logics and dynamics of their domain. Nevertheless, there is a real convergence here and, as Joppke appropriately notes, associating with the developments of political discourse those of theoretical discourse can certainly reveal interesting "parallelisms" and "refractions" (Joppke, 2004: p. 239).

On the wave of this conviction, specifically addressing the contemporary academic_philosophical, political and sociological-debate, the following reflection attempts to revise assumptions, the meaning and scope of the normative multiculturalist model, considering its original formulation and delineating the possible limits and risks inherent in the recognition of cultural rights. In particular, the aim is to rethink multiculturalism from a more properly sociological point of view, revising the terms of the contemporary debate on the regulation of the relationships between identity and otherness and its more recent developments through the sociological reflection on the structuring of mechanisms that regulate the possibility of the social order and the conditions of existence of social systems.

As was said above, the issue concerns the very foundations of social integration and social solidarity today; how difference can be treated (incorporated or integrated) and the order acquired by the difference in our increasingly multi-ethnic contemporary societies, ever more culturally differentiated. The space of sociology in the context of a debate that has, in a distinctive way, assumed tones of Political Philosophy is characterized by the availability of analytical categories that direct to reflect on the founding criteria of order and social cohesion that demarcate different visions of difference and their social implications. 
Starting from the two dimensions involved in structuring integration and social cohesion - the cultural dimension, that is, moral or normative conformity, not necessarily implying the sharing of the spirit of norms, on the hand, and the social dimension, that is, the type and strength of social ties, between individuals and society (holistic or atomistic link), informed by the cultural dimension and regulating, in turn, the degree of social cohesion, the question is the following: procedural foundations of integration, as luhmannian and elsterian sociological perspectives seem to propose, and in this case the normative multiculturalism could be justified, or, as in the durkheimian-parsonsian vision, moral foundations, a base, albeit minimal, of shared values between "us" and "them", and in this case pluralism theories would be more justified?

About it, this paper accepts the perspective of those sociological and political theories according to which, from a theoretical and empirical point of view, the sufficiency of the procedural bases seems to show serious limits as integrative constraints. These perplexities, on the other hand, increase if one looks at the issue from the perspective of the most recent scientific acquisitions on how all systems, natural and social systems, work and evolve coming from the New Systems Theory or Complexity Science.

The linear and reductionist determinism of classical science being epistemologically overcome, the concept of complex unity used to define "the system" refers to idea of an interweaving of relationships, a solidal ring, as Morin defined it, who proceeds by qualitative leaps, constraints and emergencies (Morin, 1977; 2008). In this conceptualization, Complexity redefines the relationship of determination between micro and macro (Condorelli, 2016). From the point of view of constraints, 'the system' as a condition of its existence, imposes a constraint on its parts so as to tie them and limit, reducing in unity the differences between components, without however cancelling out them, the expression of qualities which could disorganize the system itself. From the point of view of emergencies, system (the whole, the macro) is and has something more and different from individual parts that constitute it (synthesis properties), from interactions one by one taken (in case of social systems, from individual interactions between agents). Macro emerges from micro, from spontaneous interaction between systemic components, without a regulatory center, exhibiting collective properties with novelty, being not reducible to properties of individual parts and not deductible from them in isolation considered. So, in the relationship with environment to which system is open, the adaptation process is defined as a process of self-organization in reaction to disorganizing environmental perturbations, as a redefinition process of organizational configuration-and therefore of integrative constraints by which system connects the parts and constitutes itself which is an emerging result (macro) - and in this sense, a creative result as well as unpredictable, unexpected, surprising-due to intertwining of interactions between systemic components (micro). In its new organizational configuration, system hierarchically subordinates component parts to itself, knots again them to a new 
and unique whole that is maintained until a new perturbation, a new environmental input, pushes it towards a new evolutionary trajectory.

The interesting aspect here is that in this context, where the relationship between system and environment is redefined in terms of system autonomy in response to inputs coming from outside (operative closure), adaptation process expresses a self-organization capacity that system is able, however, to exhibit to the extent that it is in an intermediate position between max order and max disorder (far from equilibrium or entropy, in the edge of the chaos). Whereas in such an intermediate position there are sufficient degrees of freedom for adaptation and re-organization, the capacity for adaptation would be impossible in a system without degrees of freedom, excessively ordered (excess of integrative system constraints, like crystal molecules) or without constraints, excessively differentiated (disordered or chaotic). In the two extreme cases, the system loses it, not being able to adapt or because it is locked in an immovable order, or because it is too disordered, similar to gas molecules without any connections, unrelated and unstable, unpredictable, erratic and ungovernable in their trends. Beyond the confines of chaos, systems lose their ability to reacquire order, to survive by adaptation, to evolve towards an ever-new and emerging order. They proceed with a disorder that is difficult to reassemble into order.

This being stated, this new scientific characterization of systems, all systems, including social systems, as organization units, interweaving of constraints and emergencies, capable of self-organization, of assuming always new and emerging order configurations only if they are far from equilibrium, at the edge of the chaos (or entropy), only if far from complete differentiation and transition in that range where every form of even minimal controllability and predictability is lost, can constitute a valid point of reference for sociologically reflecting, starting from here, on current integration policies of cultural differences in our complex, more and more differentiated, individualized and globalized, society (pluralism, multiculturalism, interculturalism) and their implications for social integration. The New Systems Theory seems to be able to give new life to the debate, hooking it to a safer ground, made so by the acquisitions on the mechanisms of operation and evolution of the systems.

Starting from these acquisitions, and for what will be subsequently specified, different orders of perplexities are possible about the idea according to which cohabitation with other cultures can be assured from the device of procedural foundations of integration, and, consequently, about the normative multiculturalism that emphasizes it. Complexity language can justify the caution with which the normative multiculturalism is believed that should be considered by anchoring this judgment to the vision of a society conceived so as to dangerously visit that range of maximum differentiation, of un-relation between components of the system, which should be avoided, being identified as the range of ungovernability. The many forms of Islamic radicalism in the West and many populisms and signs of nationalistic rejection show that this is no a mere theoretical 
possibility. How to bridge this relationality deficit that normative multiculturalism, as formulated, seems to institute? How to avoid the risk of a society experiencing the inability to regain order with coherence? The Complexity framework is where the entire debate must be kept, allowing a useful analysis to understand in which direction alternative solutions can and should be looked for. Within this framework, the integration proposal of interculturalism can gain greater meaning, avoiding the risks of mono-culturalism, on the one hand, and social balkanization, on the other hand.

\section{Procedural or Moral Foundations of Social Integration? Normative Multiculturalism or Pluralism?}

The question of integration and cohesion in modern globalized societies fits into the framework of that reflection on social order which, as Luhmann said in his How is social order possible? (Luhmann, 1981), represents the problematic horizon of sociology. The issue has gathered input from the most diverse intellectual energies, from the classics of Historical Sociological thought, up to its principal representatives of contemporary sociology. Today, the problem assumes a specificity that is identified with cultural diversity, but on closer inspection, it takes on the same form it has always had in sociological interests: How to reduce differences in unity. How to integrate differences into a unified whole? And, how to unify behavior? Durkeim's and Parson's sociological response identifies the condition of existence of social systems, of society, in sharing a common ground of values. For Parsons, societies exist and are held and kept together because they have a sufficiently integrated and shared value system, some common beliefs. In other words, integration involves the acceptance of a platform of values (one common goal), which is the basis of the unification of behavior. The extent to which values are common and shared, namely the degree of value sharing and acceptance and the strength of social ties or social cohesion degree, differentiate societies, reformulating, in the transition from premodern to modern, the foundation of integration. Thus, social integration, that state of the collectivity in which individuals are willing to coordinate their actions, to cooperate under a low degree of conflict, their "making society", their insertion into an ordered network of social interactions, made possible by the stabilization of mutual expectations, has become a problem within an individualized, secularized, and rationalized modernity. Supplanting that social universe where relationships, interactions, identities, ties and corporate commitment were built, strengthened and stabilized on the deep sharing of values, rooted in the common belief in an Absolute Principle, modernity have now difficulty for its own peculiar traits (moral individualism, pluralism of values and interests, rarefaction of a transcendent foundation of solidarity) in building and maintaining a shared platform of common values for the foundation of relationships and their stability, and, therefore, of integration and social cohesion. Sociological reflection asked itself and still asks today how the order and social cohesion can be acquired by 
the difference in a modernity of choice, which is built on the laceration of a homogeneous ethical universe, restructures on this basis the interactions, forging identity unstable, weak social ties, and ultimately splitting the foundations of integration from those of social cohesion.

This problem has actually found answers that are oriented towards the difficult sufficiency of a functional-procedural foundation of integration, of interaction relationships, which does not require moral adhesion to the spirit of values that underlies the norms that govern social action, roles, institutions, but only compliance with them. In a modernity that expresses a state of incomplete integration, which weakens and breaks the relational ties, many sociological responses reason in favour of an integrative function of values, emphasize the need for a moral foundation, albeit minimal, of integration, for re-uniting cohesion and integration. They reason, as Durkheim has done, on that a priori, that element of shared common values, able to constitute today, where the individual conscience contends more and more space to the collective conscience and the value recognized to the choice divides fatally on the agreements and weakens the sense of social belonging, that common moral base which binds and integrates, creates that element of union that fosters cohesion and cooperation, tame conflicts, ensure peace and social order (it can be found in the democratic ethos of the Habermas' law production (1996), in the Honneth's human dignity (1992), in the Crespi's collective awareness of common condition of human frailty (1994); on this point see Rosati, 2001. However, the difficult feasibility of this solution is evident to certain interpretative approaches, which surrender to what can only remain in modernity, that is, the functional integration or on procedural basis (see, for example, Luhmann's or Elster's sociological interpretations).

The debate on integration is one of the most significant and controversial sociological debates of our times.

The problems on which it is enucleated are strengthened and complicated in our globalized post-modern society. The strong migratory waves resulting from the processes of globalization add difference to difference, summing up an increasing cultural differentiation in the symbolic differentiation and to the crisis of social bonds generated by the process of individualization. The already fragile foundation of the social order are under the pressure of a changed historical and social framework that adds tension to tension, making the conditions of its existence even more problematic. The problem of order in today's contemporary societies has thus assumed a new specificity, referring to how to make society with another who is characterized by a surplus of cultural diversity. And it has produced a considerable theoretical effort in conceiving today's foreshadowing of integration and social cohesion.

The problematic knot around which today's debate has coagulated is not so much whether the difference is acceptable or desirable, but rather how the difference should be treated, how "cultural differences can be included and order acquired by diversity (Hartmann \& Gerteis, 2005: p. 222; Alexander, 2001). “The 
good society", Iris Marion Young writes already in 1990, in what is among the most articulate theoretical formulations of ideological multiculturalism, "does not eliminate or transcends group differences" (1990: p. 163). But up to here, difference appreciation does not appear to be an essential requirement of multiculturalism any more than it is for other theories of incorporation, such as the pluralist-liberal incorporation model of open society or intercultural society.

All discriminating value would be concentrated on the prefigured modalities of out-group - in-group social inclusion and social integration. Again, Iris Young writes in his philosophical treatise, Justice, given the qualities of inevitability and, above all, desirability of the group differentiation in modern social processes, "does not require fusion (the melting away) of differences, but rather institutions that promote the reproduction and respect of group differences without oppression (1990: p. 47, our Italics). In fact, the crucial question seems to be focused on the need for public recognition of differences by the host society through special rights, and particular institutions, self-governed by individual specific groups. This aspect, supported in principle by multiculturalist doctrines, in communitarist and pluralist versions (Young, Taylor, Kymlicka,), is articulated in a critical form by pluralist and intercultural theories. All this reveals a substantial diversity of theoretical assumptions with reference to the dimensions that structure the bases of integration and cohesion, individual-community relationships with relative processes of identity construction, of which the prefigured models of group difference incorporation really just constitute a direct emanation.

At this point, assuming a sociological perspective, any reasoned discourse on contemporary theories of incorporation can only start by addressing the founding criteria of integration, order and social solidarity that demarcate different visions of difference, in order to then reflect upon their social implications.

The element of demarcation is the importance attributed, as a basic condition for integration and social cohesion, balancing differentiation and integration, to 1) a moral foundation-the sharing of a common symbolic universe able to guide and regulate interactions, reinforce the efforts of collective commitment, enable stable social union by reducing the levels of relational conflicts and forging the sense of social belonging (pluralism, inter-culturalism, assimilation), or 2) a procedural foundation starting from the presupposition of the non-feasibility or non-desirability of a substantial sharing of values in highly culturally differentiated societies-the sufficiency of conformity to a common legal code, to common procedural rules, norms or laws, capable of structuring interactions and ensuring collective commitment, cohesion and order, even though in the face of a profound differentiation or moral division (multiculturalism, in the dual communitarian and pluralist version).

From this perspective, assuming the integrative function of values as the foundation of cohesion and integration according to Durkheim and Parsons, the pluralist model expresses a vision of society as open, liberal, society, which val- 
ues an atomistic tie between the individual and the community, focused on freedoms and needs of the individual, and assumes as basis for integration and social cohesion a sharing, albeit minimal, of values, necessary to activate relationships and cooperation. As Sartori says, pluralist society recommends "that least bit of assimilation that is necessary to create integration" (Sartori, 2000: p. 56). In this sense, difference recognition is conceived within the framework of recognition and tolerance reciprocity.

Reciprocity understood as an openness to welcome by the host society and acceptance by those who are hosted of the host society's rules of coexistence, of that spirit of liberalism underlying the rules and regulations (the values of respect for freedom and equality which are translated into the recognition of the liberties and civil rights codified in the Constitutions of Western countries immigration, such as freedom of opinion, religious, association and information pluralism, secularism, gender equality, popular sovereignty and democratic spirit of institutions and production of law, the rule of the majority as a rule of conflict resolution) would build that relational bond and that dialogue between the groups able to reconcile respect for the difference and instances of social integration. In this manner, Sartori sees in the pluralistic reciprocity the limit of recognition, beyond which the elastic of tolerance can no longer be stretched, under penalty of survival of the same liberal and democratic society (cit:: 38), and the condition for "living together in difference and with differences" (cit: 50), without which "politics of recognition and integration mutually exclude one another" (cit: 114).

Moreover, the requirement of reciprocity, from a political point of view, legitimizes the extension to immigrants of the same civil rights recognized to the natives, that is, the recognition of undifferentiated citizenship, which can be justified only in the framework of shared participation of that liberal ethos which identifies the condition for guaranteeing individual freedom within the universal equality of rights.

On the one hand, reciprocity, along with the related processes of socialization to the essential contents of the culture of the host society, is the device to which pluralism entrusts the possibility of a multicultural society as unity of differences (e pluribus unum, see Putnam, 2007), excluding an automatic equivalence between citizenship and integration.

On the other hand, reciprocity tempers the unilaterality of the recognition, from the minority to the majority, of the assimilationist model. And yet, it represents the divide between pluralism and multiculturalism

If in the pluralist social vision politics, in the condition of the reciprocity of recognition, is geared up to protect the primary good of individual freedom, in the multiculturalism social vision, the primary good to be protected is group freedom, whose recognition is articulated in the framework of a concept of equality that overturns the terms of the liberal model, presenting itself in terms of an equal right to remain different in the context of a non-neutral, color sensi- 
tive State, of sectional, particularistic laws, and of a differentiated citizenship, all devices that, according to a pluralist interpretation, appear, instead, cause of inequality and social segmentation.

The origins of this recognition and tolerance significance, exempt from an explicit qualification that refers to reciprocity, not specifying the modes of exercise in a relational perspective between the groups, stem from a theoretical communitarian core, with its critique of the assumptions that govern the individualistic and liberal society (moral individualism, universalism of individual rights, neutrality of the state), responsible for a modernity that has fragmented social ties and identities, and in particular with its critics of Rawls' individualistic Neo-Contractualism (1971).

This theoretical nucleus, whether it is based on a neo-positivistic matrix (Taylor, 1992; Walzer, 1999; Sandel, 1982) or on a neo-Aristotelian one (MacIntyre, 1981; Etzioni, 1995), is identified in the acceptance of a cultural relativism, justified by the assumption that values are far from being able to acquire a status of objectivity and universality as they are embedded in the different concrete human communities and, therefore, relative to them.

From this angle, an evaluative comparison between cultures does not seem feasible, since it is not possible to define any dimension of values that can serve as a yardstick for comparing and measuring them. Simply, by questioning the legitimacy of an objective and universal criterion of reference, cultures appear incommensurable and can be assessed, by virtue of this condition of incommensurability, on a plan of equality: to all cultures can only be recognized an equal value, an equal respect, an equal tolerance. As Zamagni emphasizes, for the neo-communitarist multiculturalists, the cultural difference is only to be recorded (Zamagni, 2002: p. 36). That is, cultural difference requires an attitude of simple acknowledgment, the expression of a tolerance conceived in the framework of an absoluteness of value that implies the recognition of every single cultural profile as such, in its indivisible and intangible totality of meaning. And this for fundamental protection of the integrity of the community and, consequently, of the same identity of the members that in it recognize themselves.

Hence, from the defense of the community ideal as a source of identity construction, derives the justification of legitimacy of the struggles for the recognition and the proposal of a differentiated citizenship that ensures to the members of the different communities cultural the right to pursue the complex values of their own culture on public land, in addition to the individual rights recognized to all, and, consequently, to the respective individual communities the right to self-manage by virtue of the recognition of collective rights. So, Taylor, for example, referring to Mead's conception of self-formation as a social product, assumes in the recognition of difference the indispensable condition for the realization of individual identity, otherwise oppressed in the prison of a false, distorted and reduced way of being in its absence (Taylor, 1992; on the concept of oppression see the critical details of Sartori, 2000: pp. 67-68). 
It is evident that these assumptions uphold a model of social integration that does not contemplate the sharing of a platform of common values. While pluralism insists on the integrative function of a common ground, albeit minimal, of shared values among the groups, multiculturalism, as Donati underlines, adapts and legitimizes a functionalist system, inherited from the Enlightenment, which operates on the basis of the principle of equal liberty in leaving others to their destiny (see Luhmann's Sociology) (Donati, 2008: p. 31).

From a sociological point of view, however, the vision of society proposed by the normative multiculturalist model raises several questions. First of all, questions referring to cohesion and integration:

Can there be integration and social cohesion without common shared values? Is a functional integration sufficient to create, using the language of complexity, order with coherence, a virtuous balance between differentiation and integration, which safeguards the difference and, at the same time, the need for relationality and peaceful social cooperation between all the system's component, all the agent members of every group that makes up today's poly-ethnic societies, safeguarding the very survival of the system? To what extent does the sufficiency of a functional-procedural foundation of integration, supported by normative multiculturalism exacerbates differentiation, segmenting society into separate communities, unable to communicate, which do not share anything significant, disfavoring the mutual adaptation between groups and a-conflictual relational possibilities, in other words, that process, again using Complexity terminology, of self-organization of the system, deriving from a co-evolution between the system (host society) and the environment (the environmental perturbation constituted by immigration with its cultural diversity), in which the ability to acquire order and the survival of the system itself consist?

The debate is controversial. Sociologists, as Luhmann, believe that in complex, extremely differentiated and globalizated, societies, integration cannot be founded on consensus. Its foundation is a procedural foundation.

Yet, according to more than one sociological perspective, the little attention given to reciprocity and to any effort in the direction of a platform, albeit minimal, of shared/common meanings among groups, raises doubts that a procedural foundation is sufficient to integration and normative multiculturalism, born as a reaction to a sociality marked with modern individualism and consequent exhaustion of social bonds and of sense of belonging to a specific community, can be, in turn, truly decisive, guarantor of, integration, cohesion and social peace. The risk of a dangerous isolationist drift does not go unnoticed, establishing a sociality characterized by groups with strong intra-group ties and weak inter-group ties (Donati, 2008) and, ultimately, opposing against each others single communities, destined to remain increasingly alien to each other and potentially conflicting.

A broad front of criticism has been substantiated in terms like Balkanization, tribalization of society or, with another eloquent expression, formation of paral- 
lel societies (Baubock, 1996, 2004; Bauman, 1997; Carens, 2000; Sartori, 2000; Colombo, 2002; Zamagni, 2002; Tibi, 2002; Guolo, 2004; Donati, 2008; Sen, 2006b; Touraine, 2011; Rodriguez-Garcia, 2010; Maxwell, et al., 2012; Malik, 2014; Guidikova, 2014; Cantle, 2012, 2015, 2016), to indicate the multiculturalism tendency to erode the foundations of community cohesion, its inability to forge a common and shared identity, the condition of fragmentation of the social fabric in monads being impermeable to communication processes and, therefore, of potential social conflict that multiculturalism seems to establish as a counterpart to the recognition of group rights. Therefore, the implication to strengthen the lines of demarcation between the groups, stiffening the criteria of difference (of language, religion, customs), does not pass unnoticed as well as the implication to essentialize, reify cultures, understood as homogeneous entities, fixed and immutable blocks, impermiable to innovation and exchange processes (see Benhabib, 2002) and that to admit a process of non-dynamic self-formation, which blocks social actors in rigid identities (see Sen, 2006c, for his critique of the notion of singular affiliation). It is evident how all this can result in breaking up society into closed communities that are likely to problematize the conditions of integration, cohesion ad social peace.

Where pluralism, as Sartori specifies (2000), implies a particular type of structuring of society that recognizes multiple, voluntary and mutually non-exclusive affiliations, in the context of cross-cutting lines between the groups (cross-cutting cleavages) and admits identities that are constructed by free individual choice and a mutual tolerance between parties in potential conflict on the level of values, these conditions would not be possible in the normative multiculturalist model. "Blind", as Donati emphasizes, "in the face of culture as a relational fact" (Donati, 2008: p. 30), blind to reciprocity, doubts arise, from a sociological point of view, that a multicultural society of multiculturalist type, conceived to make without a minimal tie of meaning, is capable of reaching the objective of achieving order, unity, from difference. In fact, normative multiculturalism proposes no solution to possible social conflicts.

Again, from this viewpoint, even the logical validity of the concept of multicultural society is severely challenged. One can conclude that talking about a multicultural society in the normative multiculturalism sense is, at the very least, problematic: if what has been said makes any sense, saying "multicultural society" in the normative sense, would be like saying "inexteso body", that is, a logic paradox. In fact, this construct would bring together in itself two contradictory terms, two concepts in a relationship of mutual exclusion and, therefore, in logical opposition. In other words, that of normative multiculturalism seems to be the meaning in which the concept of multicultural society cannot, or should not, be used.

A separate discussion concerns, instead, the case in which the "multicultural" concept is used in a descriptive meaning. From this point of view, it simply indicates the coexistence within the same socio-political reality of more and dif- 
ferent ethnic and cultural groups. Here, the concept of "multicultural" does not contradict that of society, but simply qualifies it. In this respect, it is not a contradiction to say that a society is increasingly multicultural in the descriptive meaning of the term, as well as being absolutely true.

In conclusion, if the affirmation of cultural freedom as conditions of full individual identity realization comes to be sustained within the framework of the presuppositions of substantial cultural relativism, doubts emerge that normative multiculturalism, especially if neo-communitarian, can lead to where it promises, i.e., to a peaceful social coexistence. In fact, it seems rather to be a prelude to separation than to social integration, to intolerance rather than to tolerance, and to conflict rather than to peaceful cohabitation.

The entire previous discussion, then, leads to a second problem, that is, a ethical-social problem: is it really possible to say that all cultures are equal?

\section{Multiculturalism: Problematic Ethical Implications}

Besides the sociological and political point of view, the multiculturalist proposal of public recognition of ethnic and cultural differences maintains some problematic aspects even from an ethical-social point of view.

From an ethical-social point of view, the elements of weakness that are found in the multiculturalist proposal represent a problematic implication of axiological relativism to which philosophical communitarism, which is its substratum, reaches. They are a problematic implication of the critical objections to the modern society's individualistic vision inspired by the project of enlightenment and liberal coexistence, advanced in light of a holistic model of social relation between community and individual vs an atomistic (or individualistic) model of living together in society and the idea of neutral State.

Philosophical neo-communitarism, of which normative multiculturalism incorporates the assumptions, understands the community in the conceptual framework of a "ideal positivity. Community is always associated with the idea of a positive relational dimension, warm place, source of safety and stable identification, able to offer an answer to the growing crisis of meaning and to spreading of a condition of instability and uncertainty as they are configured in modern society. In this idealistic meaning, the concept is used as yardstick of modernity, of the progressive weakening of social tie networks and fragmentary process of identity construction generated by the disappearance of a collective telos, an ideal of good, produced, shared and enjoyed together, by the needs of the Enlightened project to found an autonomous, rational and secular morals, capable of tracing, outside any teleological and theological perspective, the founding criteria of the rules of conduct in nothing other than in the individual, in his free choice, and in his own ideal of good (MacIntyre, 1981). This transmitting of man's ideal of a good life from a community based choice to an individual choice is analyzed in its effects of fragmentation of morals and individual identity, which neo-communitarians report as the pre-eminent characteristic of 
our times. The critical notation is thus addressed to what was defined as a nullifying process of self-formation, of self-creation (Walzer, 1999), to that unencumbered, fragmented, independent, self (Sandel, 1982), that is forged in detachment from the bonds of meaning and belonging to a concrete community of values and extended affections, in the freedom to choose one's own separate project of life, and in the possibility of the continuous redefinition of one's own goals, in an incessant and never definitive work of construction and reconstruction, rather than, once and for all, in a solid sense of belonging to a group with its values, its traditions, its ideal of good, and in a spontaneous identification between expectations of personal fulfillment and interest collective (the encumbered self).

For communitarians, looking upon contemporary ethics means, therefore, recording the loss of whole pieces of the process of meaning construction, the loss of concepts such as unity, history, narration, entirely void of meaning and erased from the cognitive horizons of modern man. The reference to the self situated condition in opposition to an unencumbered self (Sandel, 1982), the consideration of a frame of reference by the light of which we can build our own identities (Taylor, 1992), the insistence on the virtus tradition (MacIntyre, 1981) are all ways, different in formulation but substantially the same, to appeal, instead, to a life project rooted in the pre-fixation of what is socially assumed to be both good for man and good for the community, in the conceptualization of a good that comes first, towards which we should tend, of a telos established and shared in a community way, on which we can structure the conception of a life understood as unity. Thus, the programmatic conclusion is foregone: to combat the disruptive effects on morals and identity produced by liberal individualism, favoring the return of and to the community, to the warm circle, to strong social bonds, to the "passionate ardor" in the political arena (Walzer, 1999) to that only social dimension whose characteristics can assure the recovery of the virtus ethic.

These community's characteristics are those which, for its part, also a long sociological tradition, from Simmel to Tonnies, from Durkheim to Rosenberg, has outlined in antithesis to calculation, impersonality and individualization characteristics of non-communitary social relations.

Communitarian reflection on the alarming state of feelings of belonging loss, of social tie instability, of contemporary identity inconsistency and fragmentation, is in accord with sociological interpretation of the crisis of social cohesion induced by modern individualism in post-modernity. For example, in that palimpsest identity, that Bauman (1997), recognized as the condition of post-modern man, is summarized the activation of a self-formation process as an ever changing new game, always open to new solutions, calibrated on the right to a choice without fixed rules, with no commitment nor memory, where identities can be adopted or discarded with the same speedy ease and indifference of a "costume change" (Lasch, 1985: p. 34), sweeping away the stability of every bond, and 
transforming what was once, in pre-modern times, a question of responsibility and moral obligation into a question of taste and continuous negotiation. From Giddens to Bauman to Beck, contemporary sociological reflection shows an increasingly fragmented and uncertain sociality, an ever weaker network of social bonds, as sign of a human condition in which there is no longer history but a collation of episodes, there is no time but an eternal present, indifferent to its past and its future consequences, a culture of the ephemeral, the provisional, the uncertain, in which traditional, creative of meaning, oppositions collapse (between the certain and the uncertain, order and disorder, the expected and the unexpected, transitory and eternal, normal and pathological, reality and appearance), in the continuous transcendence of fixed boundaries and progressive adiaphorization of human actions (Bauman, 1997; 2004). The modernity interpretation is dual. If, on the one hand, the valorization of individual choice, of individual needs and freedom over community good, it is an opportunity for freedom from the restraints of tradition, nevertheless, on the other hand, a modernity where social relations are undermined by a diffused state of moral indifference, a diffused tendency to undress (and dispense) a good portion of human actions from all moral significance, exempting them from ethical evaluation, appears to Bauman a normal condition of post-modern social life. Bauman's global individual has lost an evaluation rule of what is happening around him, and his ability to evaluate is weakened, with the danger that this state of moral indifference can become the condition by which any solution, even the worst, can be administered, the ground for new form of tolerance and solidarity or social conflict.

From this perspective, as Alexander observes, there is certainly something positive and pleasant in the idea of a collective identity, built on a solid group culture, with traditions and values of fundamental importance, capable of forging a sure sense of belonging (Alexander, 2008). A wide selection of sociological literature has underlined this aspect (as Bellah, or Etzioni), looking back with regret to the twilight of the community ideal and obligations, of the bonds of loyalty that keep a community alive (cit).

However, this is a partial vision (ibidem). Community, as source of identification, implies a sharing that ties, distinguishing among "us" and "others". Nevertheless, in spite of attractive characteristics of community life, including the attention to solidarity within the group, the bonds of loyalty and affection between the members of the group, it is not exempt from problematic implications, like the often ambivalent relationship between community and freedom (Bauman, 2001), safety and felicity, a massive conformism that can accompany community both with the inter-group conflict and with the intra-group oppression, with the protection and the perpetuation of traditions, customs, practices founding of profound social inequalities, as in the case of the condition of women in sexist societies. Sen clarifies this point well in saying that the community life does not exclude the risk that the use of reasoning can be replaced by a critical acceptance 
of conformist behavior leading to choices that would otherwise be rejected and having conservative implications by protecting customs and practices from intelligent critical analysis. In this meaning, the community is the fertile ground in which inequalities that derive from tradition can survive, by making the corresponding identities a question of unconditional acceptanc, rather than the object of critical examination (Sen, 2000 [1999]: p. 27).

Sen underlines in this way the problematic aspects of a social vision focused on a relationship between the individual and the community conceived as a unicum, wherein in principle the community must always and in any case come first, before and against any individual choice, and therefore before the reason that orients the choice (ibidem; Sen, 2006c).

The communitarian device contributes to explain certain dark chapters of our history such as the separation of Jews into ghettos leading to the Holocaust tragedy, the various forms of discrimination and segregation of the black population, former Yugoslavia, Rwanda, the Kurds, Armenians and Egyptian Copts massacres, to cite only a few cases of a long string of examples from yesteryear to the present day. Likewise the Inquisition could have arisen solely in the context of the totalizing teleological social vision of the Middle Ages. These events were realized, precisely under the shadow of a holistic collective ideal of life, the community, with its ideal of good that entwines its members into a single knot, from purity of race to traditions of faith, from having to affirm or protect against a them, the outsiders, and nevertheless designed to dampen and choke, within the group, the centrifugal thrusts in favor of massive group conformism.

For the same reasons, certain traditions, that legitimize profound social discrimination, can survive for the sake of the collective good as normal, accepted a-critically as such, not disputed, perhaps even by those who are actually subject to the discriminating content of traditions:

Several examples can, indeed, be mentioned in this regard: the difficult breakdown of social immobility promoted by the Indian caste tradition; the personal identity denied to women by the religious India of the tradition and the sacred ideal of pativratya, formerly annulled, if widows, by the sati sacrifice or, particularly in today's northern India, by a social death which represents them as white shadows begging in the temples of Vrindavan, surviving by means of alms and prayers in the city's ashrams, or, again, the condition of many Muslim women closed by the Koranic tradition in a real scriptural prison, devoid of any social visibility and subservient to male domination; and the many women of Kabul stoned, as late as yesterday, in public squares, in the name of safeguarding morality and the unity of the Islamic umma.

In other words, the ideal of community good, depending on the contents that characterize it, can create separation, raise social barriers, radicalize, oppose differences, operate and justify serious social discrimination inter and intra group forms without any individual and social responsibility being felt. The problem becomes the meaning which in this context, assumes the determination of a 
principle of attribution of individual a collective responsibility and imputability. In what sense, can Kabul man feel responsible for the act of lapidation? Or for the death of an apostate? The same question applies to the lynching of American blacks, to Indian women of Calcutta and those of Kabul, to the persecution of Jews or Coptic Christians in Egypt, and so on, to any form of social discrimination rooted in ethnicity. In other words, what in modern societies, with their insistence on individual choice, is no longer questionable, can become a problem.

In conclusion, the fact that the liberal individualistic project proved to be illusory, producing a permissiveness that compromises the social, and identities incapable, once and for all, of recognizing themselves in solid references and agents of unstable relationships, always negotiable or liquid, as Bauman says, is, as already mentioned, the object of a long sociological tradition of analysis of post-modernity, struggling with the community/individual dilemma (Bauman, 2013). And nnevertheless, if it is true that the isolated individual, a pure ego, totally self-referential, a sort of microcosm that is formed independently of any relational process, is an unthinkable entity, Sociological analysis leads us to look with caution at community living. This is the sense of Sen's objections, when he observed that in principle, the community cannot always and in every case come first, beyond any possible scrutiny.

That being said, this question directly addresses the debate on management of cultural diversity reverberating on normative multiculturalism, on what Shachar has called, the paradox of multicultural vulnerability (Shachar, 2001: p. 3). The paradox of multicultural vulnerability recognizes in the normative multiculturalism the risk of contributing to maintaining, paradoxically, in the name of the defending the right to freedom and tolerance cultural, values and practices capable reproducing social inequalities within minority groups, violating the individual rights of those, such as women, being the object of such discriminatory practices (e.g, Okin, 1999; Phillips, 2007) ${ }^{1}$.

From this perspective, the position of incommensurability between cultures, with its attacks on the liberal, neutral, Secular State (a State, considered color blind precisely for this reason), risks emptying of meaning any discourse intended to conceptualize criteria of moral, cultural and political progress (Boudon, 1999).

Ethic limits have been widely treated in academic debate. For Heller, the rule of multiculturalism can become an instrument of abuse and imposition when the decisions of individuals are prejudiced or subject to generalized preferences (Heller, 1996: p. 34). Which means, according to the author, that Multiculturalism, as a utopia of the same opportunities for all the communities and for the individuals recognized in them, is destined to remain an incomplete utopia if it ${ }^{1}$ Liberal Muslim and Muslim secularist feminist movements critique seem to move in this direction. It is particularly significant in negating policies of identity, held to be responsible for favoring, in the name of cultural tolerance, the condition of intra-group discrimination toward Muslim women, within the most part of European States, rather than encouraging responsibility processes of Muslim communities towards their members (see Tibi, 2002; Samir Khalil, 2007; Manij, 2004; Tamzali, 2010; Sbai, 2010). 
reifies cultures, if freedom, as a superior value, that is, the possibility to belong or leave any cultural community, native or not, as an act of free choice (ibidem), is not incorporated into the same utopia,. If this possibility (as in the case of mixed marriages or acts of conversion to another faith) is not accepted, but sanctioned, impeded by force or even death, multiculturalism risks falling into that illiberal confusion mentioned by Sen (2006b), into that protection of forms of intra-group oppression that deny that instance of freedom, equity, and social justice that normative multiculturalism would wants, instead, to guarantee.

Boudon seems to have put an end to the question by saying: "that the 'cultural' rights of groups and subgroups must be recognized is one thing, that this should imply the acceptance of axiological relativism is another" (Boudon, 1999: p. 45).

In short, multiculturalist model appears to design a sociality that cannot find common points of union, a society made up of separated, unrelated, closed, groups, potentially in conflict on the level of sensitive values of social relational orientation, such as equality and social justice, and for which it is difficult to talk about integration, cohesion and social equity.

The fundamental question, then, becomes that of identifying a solution for civil coexistence among different cultures which can avoid incurring the negative effects of ethical relativism, and which is, at the same time, the guarantor of integration, of order and social peace, of equity and reasons for cultural freedom. The solution, presently most debated is that of inter-culture. For its part, even pluralist multiculturalism, which appears to be less radical than the community solution on some points, seems to leave open the same problematic issues discussed up to now.

\section{A Complex Issue: A Recognition Threshold}

Our previous observations raise the need of a recognition threshold. But exactly, how complex is its definition? I shall limit myself to some considerations.

Multiculturalism in the pluralist version (Kymlicka, 1995a; 2018) seems to set this threshold admitting the non-recognition of traditions opposing liberal principles (as, for example, in the case of Islamic culture groups: polygamy, infibulation, talaq divorces, arranged marriages and so on. On the other hand, it supports the implementation of interventions that would make liberal institutions truly accessible and usable by immigrants (for example, school curriculum adjustments, adapting standards for job selection to curriculum, modifying times and workplaces, dress code adjustments), and admits the recognition of institutions conforming to the specific traditions of the immigrant community, in particular schools, hospitals, houses, and cemeteries. The underlying assumption of pluralist multiculturalism is that immigrants are generally willing to integrate within host countries and, therefore, willing to give up those practices that encounter a negative judgment of illiberalism in host societies. The request of including "pieces" of minority group culture in our institutions (Zamagni, 2002: p. 
235), that is, the request of a differentiated citizenship seems to remains in the social-democratic domain.

However, from a sociological perspective the model of cohabitation and integration proposed by pluralist multiculturalism, does not get rid of those relational short-circuit problems and balkanization issues previously observed. From this perspective, even in its more temperate version, multiculturalism, with its differentiated citizenship, implies certain caution on social-political and ethical levels.

Even in this case, the model is based and insists on the integrative function of law, of the norm. Therefore, the admitting of the renunciation by immigrants to follow in the public space certain traditions far from the liberal cultural principles of Western societies does not require the sharing of the spirit of the norm. In fact, even here, certain institutions are thought to be separate from those of the host society, including main institutions that preside over socialization: schools. In the end, the main question remains open to debate, that is, whether the integration needs something further than sic et simpliciter compliance with the rules. There would always be a lack of that meaning bond, that platform of shared values at the base of cohesion and integration, that enable "to make society", common world, reducing the risk of a segmentation of the social fabric into non-communicating, in potential conflict, sub-communities.

In other words, the initial question, recognition threshold, manifests itself in its entire complexity.

Also Pluralist multiculturalism, with the recognition of differentiated public institutions, which are organized according to the ways of different cultures, establishes a relational short-circuit which, in the absence of true reciprocity, separates groups, estranges them, undermines a stable and peaceful social commitment. Furthermore, it can lead to new forms of social injustice, for example when certain cultural profiles, inspired by traditional social gender constructions sanctioning the social inferiority of women, extend to include the way of understanding care strategies, the organization of public and domestic spaces, inheritance issues, family responsibility, and the weight of women's witness at court trials..., (e.g. in the case of Islamic communities). Recognizing, in principle, differentiated public institutions may risk compromising the right of women to health, justice, and life itself, to those universal rights that respond to the values of freedom and equality, which distinguish the liberal culture of Western immigration societies.

Sociological analysis on the bases of integration, leads us to believe that, in both multiculturalism versions, multicultural recognition, which should reduce conflict and lead to social equity and peaceful coexistence, is not the most suitable device to guarantee because it favors cultural separation and renders fragile the possibilities of cohesion and integration, of peaceful social cooperation, as well as of social justice.

This is not merely a matter of theoretical possibility. As stated in the introduction, the choice of conducting the discussion on a theoretical level is motivated 
by the conviction of its usefulness for understanding concrete empirical situations of conflicting relations between groups. On one hand, we witness many cases of radicalism of Islamic tradition and fundamentalism, and, on the other hand, many cases of populism, invasive xenophobia, nationalistic closure reactions. The widespread recognition of Sharia courts in England, for example, in a more or less multicultural temperate climate, has ended up by perpetuating traditional gender discrimination (i.e. discriminatory judicial sentences concerning inheritance, the impunity of violent husbands in domestic violence cases, which follow the dictates of Koranic Islamic tradition).

In short, defining the threshold of recognition is not a small matter. Okin's views on group rights as a possible obstacle to freedom of choice, and in particular to the choice of women and their existential well-being, seem to remain valid (Okin, 1999).

In the framework of pluralist and communitarian multiculturalism, differentiated citizenship appears to be the cause of problematic implications on the ethical level and on integration and social cohesion levels as well.

Nevertheless, even undifferentiated citizenship requires strong caution as it relates to social integration, acquiring value only in the framework of reciprocity, of minimum bonds of sense, without which undifferentiated citizenship may establish a dangerous automatism between citizenship and integration (Sartori, 2000). The risk might be a purely instrumental use of rights, which could compromise the very survival of society.

In this sense, from a sociological perspective, pluralism would avoid these dangers as much as those to which multiculturalism exposes, emphasizing the importance of a common shared symbolic code, as a necessary condition of order, and integration. As we read in Rusconi, for example, the acquisition of citizenship cannot be just a matter of acquiring subjective rights, but a commitment to contribute to their production (Rusconi, 1996: p. 3). As previously mentioned, this bond of meaning is identified in the sharing of a democratic ethos (Sartori, 2000).

In this respect, Habermas' inclusion proposal is significant ${ }^{2}$.

In a modern society, where the progressive contraction of the collective consciousness has given way to individual consciousness, to the construction of an individually chosen biographical project, differentiating the symbolic universe and making a platform of shared values and sense of belonging increasingly problematic, Habermas insists on the integrative function of the norms and procedures of democratic law production.

${ }^{2}$ Unlike Kylimcke and Taylor, Habermas excludes that the valorization of differences requires group rights recognition, since the system of individual rights is sufficient. In fact, given the condition of co-originarity of private autonomy and public autonomy (Habermas, 1996), all we need is a procedural legal democracy, capable of guaranteeing both private and public autonomy. Therefore, for Habermas, collective rights would not be necessary, provided that the legal coexistence of the various cultures is equated; that the State undertakes to realize the conditions (or procedures) that would allow everyone equal opportunities, ensuring a transversal, not mono-cultural, participation in the public arena. 
In final analysis, according to Habermas, sharing a democratic ethos is the true guarantor of integration in individualistic and culturally differentiated democratic societies. For Habermas, it is not necessary to recognize special group rights, but simply to extend to immigrants, especially second generation, born in the host society (ius soli vs ius sanguinis), full citizenship with all the rights that ensue, including the right to vote, so as to be able to participate in democratic political dialectics and be able to reach a possible public recognition of their interests simply by following the rules of democracy and pluralism. Habermas proposes political integration, according to patriotic constitutionalism which implies an acceptance of the rules of production of laws and power, considering that moral integration cannot be demanded by a liberal state (Habermas, 1996). However, it is evident that Habermas refers to a common basis of values among different cultural groups, that is, to sharing a democratic ethos as a priori to social action.

In other words, starting from this sociological perspective on integration, the conferral of citizenship can constitute the conclusion of a path that can find in it not so much the point of departure but rather that of arrival. Before a democratic and liberal spirit matures and is shared, the risk is that the conferment of citizenship creates nothing other than a fertile ground for an instrumental use of democracy. Through the exercise of democratic measures of representation (right to vote, of association, ...), this use can, in fact, be functional to advocate and support practices that are not expressive of that same pluralist and liberal spirit that justifies the attribution of subjective universal rights, to the detriment of social cohesion and integration, ad of the very survival of modern, individualistic, liberal and democratic societies.

Regarding this question, Sartori, in 2000, was already wondering, for example, why a large Islamic community which had obtained citizenship, aware of being able to influence electoral destinies with their vote, did not add to the usual requests advanced to the Italian State through the UCOII (the recognition of Koranic schools and marriages celebrated with Islamic rites, festive Fridays, the possibility of pausing work activities for noon prayers, authorization of photos with veiled faces on I.D. documents of Muslim women) requests relating to polygamy or infibulation, not mentioned for the time being. In other words for the well-known political scientist, integration can only take place between individuals who want to be integrated. Without this fundamental condition, when foreigners who do not want to be integrated are turned into voting citizens, it is not difficult for Sartori to consider that a procedural foundation of integration is insufficient ad to imagine a very conflictual society.

And so we return to the main question, namely: how far must an identity policy go? What is the threshold of recognition beyond which it is not possible to go without compromising the reasons of integration and social peace? How can we to fill up for the purpose of social integration the "lack of relationality between cultures that multiculturalism institutionalizes" (Donati, 2008: p. 30)?

Up to here, some points can already be reported. Cultural diversity amplifies 
the problematic nature of an essentially functional integration model. Overcoming the socio-ethical-political problems connected to the model of public recognition of the differences proposed by multiculturalism implies the need for a condition that the pluralist model, as well as the intercultural model have developed, namely the need for an intercultural pedagogy. A pedagogy designed in institutions not separated by certain main institutions of the host society (schools, hospitals, courts, etc.), as these institutions reflect in their structure the liberal-democratic values of the culture that informs them. This would not be a matter of cultural homogenization, but of a functional answer to the needs of a social integration in which groups can cooperate, recognize, dialogue, and relate on the basis of a common language interwoven into a minimal core of shared meanings.

This model of cultural differences management would, therefore, be placed in an intermediate position between multiculturalism and proposals of assimilative and homogenizing mono-culturalism, ensuring, at the same time, the recognition of those cultural differences that are not a problem for democratic culture and allow groups to participate in public life (recognition of places of worship in which they can freely express their faith, cemetery departments where they can bury their dead according to their customs, or certain festivity related to the cult. Likewise, this applies to certain food customs or certain styles of clothing, although the debate, for example, on the use of the veil for Muslim women in the West shows how even in reference to clothing styles, the reconciliation of the right to cultural identity with the protection of individual rights to freedom of choice, may, in some cases, be problematic).

Therefore, it would be a matter of overcoming a multiculturalism that risks ending up in social segmentation and cultural indifference (Bauman, 2001), and to get out of what Sen (2006b) called illiberal confusion with the mediation between community rights and individual rights, guaranteeing the individual from both community and anti-communitary pressures.

In conclusion, from my sociological perspective, integration requires that recognition of cultural diversity finds its limitation in reciprocity. From this perspective, integration requires mutual availability to openness and acceptance, as well as conditions capable of guaranteeing the creation of a common ground of shared values for a mutual and peaceful fertilization of cultures. As we shall see in the concluding section, the problem may find a solution within the framework of the integration proposal of inter-culturalism, which seems to create the best conditions for overcoming both mono-culturalism and multiculturalism as a pluralism of monocultures.

\section{Multiculturalism Backlash in Europe: The Case of Islamic Immigration}

So far, we have seen the limits that have been attributed to the doctrinal formulation of the integration proposal based on the recognition of group rights. Moving from theory to practice (by considering surveys data being more cur- 
rently available), a real convergence can be identified between academic and political discourse. In this sense, theoretical reflection appears useful for understanding concrete empirical situations.

In particular, the case of Islamic communities in Europe appears to be an example of the problematic aspects which multiculturalism can give rise to. In fact, Islamic immigration in Europe highlights the weakness of the normative multicultural model, and the value of reciprocity as the foundation of integration and cohesion.

All over Europe, more traditionalist Islamic communities, with their apology of unanimism, their holistic individualism, and certain cultural profiles far from being liberal principles (rejection of secularism, popular sovereignty, human rights as an individually recognized asset), seem to have posed the most serious problems to integration and social cohesion. Unlike other communities, such as, for example, Filipinos, Mauritians, and Chinese who, despite possessing a strong ethnic identity, usually accept the host society's rules of cohabitation without making any requests for public recognition, neo-traditionalist Islamic communities, on the other hand, claim autonomous institutional spaces; they advance requests to the State of host countries for public recognition in order to avoid the reduction of Islam to religiosity, lived out in public spaces, in the arena of simple private spheres (among the main ones: recognition of places of worship, schools, festivities, marriages with Islamic rites, food and clothing practices, such as the use of veils for women, ...). In other words, on the basis of a multiculturalist interpretation of the recognition of difference, neo-traditionalist Islamic communities opt for the recognition of special rights that allow them to live in the host society without "necessarily, having to opt for greater cultural integration in the settlement society" (Guolo, 2004: p. 105). In this way, they reproduce the rigid separation between the pure and the impure, the house of God and the home of the Infidels, lost through emigration, an ideological hijra marked by an insignificance of relationships with the autochthonous. It is the option of an externalized integration, as Guolo calls it, which does not aim at the individual's integration but "at negotiating on a collective basis of a statute of derogation of citizenship which defines the degree of self-exclusion necessary for the reproduction of community separateness" (Guolo, 2004: p. 103).

Of course, Islam is not a monolithic universe. There is also a liberal Islam which advocates of modern secularism and modern exegesis of the sacred text, in light of the recognition of pluralistic and liberal-democratic instances of contemporaneity. It is the Euro-Islam of Bassam Tibi, and that of Samir Khalil Samir, of Souad Sbai, of Heggy Tarek, of Irshad Manji, of Muhammad Al Houni, of Khaled Fouad Allam and of many other liberal intellectual Muslims who believe in the possibility of adapting and making Islam compatible with the liberal and democratic principles, codified in European constitutions. According to Samir Khalil (2001, 2007), for example, whereas a relativist multiculturalism strengthens fundamentalism, the only possible model for positive coexistence 
should aim at building an enriched identity. Likewise, Tibi (2002) proposes a dialogic approach that recognizes the importance, for peaceful civil coexistence among different cultural groups, of sharing a common values platform, of minimal consensus on values belonging to host society culture, such as: democracy, secularism, religious pluralism, civil rights, and respect for human dignity. In other words, it is important that "other" communities maintain their identity, while respecting the Leitkultur, that is, the host societies' liberal cultural profiles for a mutual fertilization of cultures.

Yet, in Europe, neo-traditionalist leaderships are particularly active in co-opting immigrants toward a path of communitarization.

After thirty years, as multiculturalism has slowly gained ground almost everywhere in Europe, in countries such as Great Britain, Holland, and Denmark, which have long experimented with the application of well-founded policies, despite singular local varieties, on the principle of the recognition of group rights, the acceptance of requests coming from traditionalist Islamic minorities and the possibility given to them to organize themselves starting from their own cultural traditions seems to have created problematic consequences. In fact, the recognition doctrine of cultural rights, once it became a political practice, seems to have favored the separation among groups, and cultures, detrimental to the sharing of common and unifying values. It has caused ethical relativism, the birth of parallel and self-referential societies with strong relationships within themselves but fragile and potentially in conflict on the level of values with the rest of the host society (Cantle, 2001, 2016; Grillo, 2007). In this regard, Sen observed that the history of multiculturalism is a good example of how fallacious reasoning can trap people into the inextricable quagmire which it has created (Sen, 2006b: p. 35). This would explain why, in the Netherlands, for example, there were heated, intense debates on the limits to be imposed on the expression of different cultures and on the need to promote more effective integration policies (Korteweg, 2006; Vasta, 2007), after the claim of director Theo van Gogh's murder by a Dutchman of Moroccan origin, charging Van Gogh with offending Islam with his filmographic denunciation of the subjugation status of Islamic women. Not unlike Great Britain, where in recent years, particularly after the New England revolts in 2001 and the attacks on the London underground in 2005 , there seems to have been a growing radicalization of a large part of the Islamic community in affirming its cultural specificity, and feelings of alienation from the host society rather than integration (Hart, 2005; McGhee, 2005, 2008; Kepel, 2005).

Indeed, the post-colonial policies of Great Britain, one of the societies with the greatest cultural diversity, constitutes the most exemplary case of public commitment towards the maintenance of cultural and religious specificities, conceived as a measure of social cohesion. By interpreting equality in the light of the difference recognition, the English multicultural model has assumed communities, represented by reliable local interlocutors, as spokesmen for individuals, 
recognizing differentiated juridical treatment, community rights to a individual who is identified as community, as belonging to a specific ethnic-religious tradition. As was said above, Islamic communities, with some of its cultural profiles far from liberal principles (rejection of secularism, popular sovereignty, human rights as an individually recognized asset), seem to have caused in Britain, as well as everywhere in Europe, very serious problems regarding integration and social cohesion.

Instead of seeing, as expected, a progressively growing integration between Islamic minorities and English host society, during the last twenty years, the influence of the most radical Islamic ideological tendencies seems to have increased, refusing to place religion in the private sphere and claiming recognition, on the public scene, of values, customs, social relational rules inspired by traditionalist practice of Islam and sanctioned by the Shari'a. In this regard, for example, since 1982, the right was recognized to the Muslim community to establish and to manage autonomously the courts that exercise the function of judgment by applying the Shari a as a source of civil law. This has led, since then, to a dangerous legal pluralism, endorsing the emission of discriminatory sentences against Muslim women in matters of inheritance, marriage, patrimonial disputes, education and assignment of children for example, but also of domestic violence, with the substantial impunity of violent spouses (mostly sentenced to follow anger self-control courses), according to the dictates of the most radical Islamic tradition (Sbai, 2010). This recognition seems to have been the favorable condition for Islamic community closure into its own cultural profiles, as well as for demonstrations organized by groups of young British Muslims (Islam4UK), aimed at supporting the introduction of the Shari'a in the body of British judicial law (Sbai, 2010).

Already, a survey carried out in 2006, on the attitudes of British Muslims (published by the Sunday Telegraph) showed a growing radicalism among Muslim communities: $60 \%$ of Muslims interviewed (more than 500) felt alien to British society and were in favor of a lifestyle based on the most radical Islamic ethics, $40 \%$ advocated the application of Shari a in predominantly Muslim areas of Great Britain, and 20\% showed sympathy for the feelings and motivations of the Shahid responsible for the 2005 terrorist attacks, from educated youths, second or third generation offspring who were apparently well integrated into English society and born into families immigrating to Great Britain two or three generations ago.

Despite the variety of locally adopted multiculturalist political strategies, the principle followed for integration was to practice an openness to safeguard the ethnicity of identity minorities without asking anything from the immigrants in return (Joppke, 2004). However, it seems that the reciprocity, necessary for a fruitful meeting of cultures, was compromised. Already in 2001, the Cantle Report described multi-ethnic Great Britain as a collation of separate communities, with parallel lives in separate institutions, incapable of meaningful interchanges, 
lacking a meta-community as a common ground of union between ethnic-cultural differences (Report Cantle, 2001: p. 9). Even the studies conducted on the growing ethnic tensions that occurred in various English schools in response to multicultural educational approaches (e.g. Faas, 2008) push in the interpretative direction of a growing process of stiffening of the ethno-national boundaries, as well as the most recent government reports on the status of Muslim women in Britain.

The latest reports from different parts of Europe, still present a scenario where the condition of Muslim women is strongly anchored to a tradition that is reluctant to open up to parity principles and to the promotion of fundamental subjective liberties and, therefore, subordinated to the imposition of rules that deprive women of self-management, first of all the custom of forced or arranged marriages. These traditional rules are widely followed in Great Britain, as well as in Holland, Belgium, Sweden, Norway and Denmark. Already in 2009 a report presented to the Council of Europe showed that in Northern countries there was a progressive a growing re-traditionalization and re-patriarcalization of Muslim women's status, indexed by a progressive increase in the last twenty years of domestic violence carried out on the basis of traditional codes of honor, which punish, in the name of the unity of the community, the opposition of resistances to the Islamic cultural/religious tradition (the arranged marriages refusal, the refusal to convert to another faith and to wear the Islamic veil, the inclination to wear Western style clothing, to frequent Christian friends or, in any case, non-Muslims, to study, to undertake a career, to seek divorce, to be independent, in this sense, to be modern (Council of Europe Report, 2009).

One of the most recent reports on honor-based violence was written in 2011 by Iranian and Kurdish Women's Rights Organization in Great Britain (IKWRO, 2011). Murders, rapes, abductions, physical and psychological violence, and acid disfigurements increased by $47 \%$ in Great Britain in 2010, for a total of 3300 offenses recorded by police stations (without considering non-reported cases). The areas with the most crimes were urban areas, where the largest number of Muslim immigrants resided: 495 crimes in London, 378 in the Birmingham area, 350 in West Yorkshire, 227 in Lancashire and 189 in Manchester. The trend appears to be confirmed by more recent reports. Overall, from 2010 to 2014 the British police have recorded more than 11,000 cases of honor bases violence (abductions, beatings, homicides) (IKWRO, 2015). In addition, this violence, based on an honor code, does not seem to limit itself to first generation immigrants. According to the detailed Crimes of the Community report about Honor-Based Violence in the UK in 2010, this violence was also perpetuated by third- and fourth-generation immigrants who grew up and were educated in the UK and was justified by 1 out of 10 young Asian Americans.

In addition to the general picture, the estimate of Muslim women living in England and Wales coming from countries where the practice of infibulation as a prenuptial condition is tradition, rose from 66,000 in 2001 to 137,000 in 2011 
(Macfarlane, 2014). Based on these data, it is estimated that about 20,000 women are considered at high risk every year ( $A$ Statistical Study to Estimate the Prevalence of Female Genital Mutilation in England and Wales, Foundation for Women's Health and Development, 2010). Furthermore, it has been estimated that currently about 300,000 Muslims live in the UK in polygamous families without incurring any penalty whatsoever; the number of forced marriages have doubled in just 4 years, from 1996 to 2000 with a total figure of 18,000 cases in the year 2000 (Home Office, 2000). Each year, there are about 8,000 British women of Turkish, Kurdish, Iranian or Pakistani origins, forced to undergo arranged marriage by their family (Report of the British Department of Education, 2011) and often, they are under 18 years of age (British Government Department for Forced Marriages, 2010, Report from the Foreign and Commonwealth Office, 2012).

After having favored the opening and the conferring of special privileges to religious confessions-with the establishment of Shari a tribunals and Faith Schools, where, however, a radical interpretation of Islam has been shown to condition scholastic programs (punishment of apostasy and homosexuality, discriminatory conception of the sexes, type and modality of corporal punishment in case of deviance, aversion to the Jews....) and promote a strong identity closure and clash-the multiculturalist English society myth has had to deal with critical issues that have led to a rethinking of group rights towards policies aimed at promoting a greater sense of citizenship and national belonging: greater use of the English language, greater acceptance of the main national institutions. In this regard, the Cantle Report had already concluded by suggesting this need, reaffirmed by the 2002 White Paper, which insisted on the "duty" of immigrants to a "mutual understanding" for the creation of a common and shared vision of society (Home Office, 2000: p. 27, cited in Joppke, 2004: p. 252). As recently as 2011, at the Security Conference in Munich, British Prime Minister Cameron declared the "failure" of State multiculturalism and its necessary downsizing in the name of universal human rights of freedom and democratic values. The government leaders of Germany, Denmark, Holland would go on to echo these thoughts.

In Holland, there has been a similar shift from multiculturalism to civic integration since 1998. In the shadow of group rights official policies, as Entzinger pointed out, an ethnic sub-class with weak links to Dutch culture and society, without any intentions to integrate, seems to have emerged (Entizinger, 2003: p. 78). In 2004 a Government Report showed that in the Netherlands, after a long multiculturalist tradition, Muslims of first and this is certainly the most significant aspect, second generation are not willing to accept modern conceptions on women's emancipation and the role of religion in society, i.e. the perspective of the secular state that shifts the social role of religion from the political-institutional public level to the level of the intimate dimension of religiosity (Government Report, 2004). According to 2008 data from the Ministry of Jus- 
tice, domestic physical or psychological violence against women is a systematic practice in at least two thirds of Turkish and Moroccan families living in the Netherlands: $21 \%$ of Turkish women and $14 \%$ of Moroccan women were victims of family abuse. Here too, the novelty in the current Dutch integration policy consists in requiring more from immigrants in the process of integration, reducing the practice of a unilateral cultural recognition from the dominant society to minorities. The most visible expression of this new propensity is the 1998 law on civic integration of new non-European arrivals which obliges them (albeit with soft sanction provisions) to 600 hours of civics and host language learning.

This political rethinking about principles of civic integration has become a rather general trend in Europe.

In Denmark, there was a law promulgated in 2017 for de-radicalization, with prevention programs entrusted to primary school education.

Since the 1970s, in Germany, several radical movements have been working to Islamize Muslims, mainly Turkish, in an extremist manner. Although multiculturalist policies have not been officially applied there, as in Great Britain and the Netherlands, various governmental agencies such as the Federal Foreign Affairs Commission have supported and promoted a concept of Germany as a multicultural country. In the last twenty years, as Souad Sbai reports, cases of Shari a infiltration seem to have increased (Sbai, 2010): in the courts, with sentences that have recognized cultural extenuating circumstances in cases of honor and domestic violence because they are considered legitimate by Koran principles; in schools, where Muslim students are given the right not to study evolutionary theories without any negative scholastic consequences and male teachers are invited, in some cases, not to shake Muslim students' hands at graduation because it is banned by Islam; in censorship, where various classical theatrical representations are canceled in order not to offend Islamic sensitivity; in eating habits, where Islamic slaughtering is allowed.

As reported by widespread literature, here as well, however, these forms of respect for cultural Islamic sensitivity seem to have not produced a proportional growth of the internal state of social cohesion, but rather affirmed the relativism of values and the separateness of minorities from the mainstream (see for example Lust, 2008; Prins \& Saharso, 2010). In 2010, statistics reported, for example, an increase in domestic violence with as many as $49 \%$ of Turkish women suffering domestic violence in the family (Sbai, 2010). Against this background, the revaluation of the notion of Leitkultur in German political discourse assumes the same significance as political rethinking in the direction of interventions for civic integration in Great Britain and in the Netherlands (Joppke, 2004).

In Sweden, the most recent national study, conducted within the European project: Flying Team against Violence, estimates that 70,000 Muslim girls are at risk of forced marriages in Sweden (Gift mot sin vilja-Married against One's will-2012). This trend places within the more general European framework. 
Downing Street estimates that about three thousand forced marriages occur in Europe every year, while thousands of Muslim girls, often European citizens, disappear. In order to face this emergency, in the last 10 - 20 years, Forced marriage was declared a criminal offense, punishable by law for up to 6 years in prison, in Belgium, Norway, Germany, and recently in Great Britain, where current legislation on this matter, only allowed civil court proceedings.

In short, the lack of attention given to reciprocity and policies aimed at building minimal consensus on host society values seem to have ended up by strengthening barriers among groups and destabilizing the foundations of cohesion and integration.

According to many interpreters, Europe is a case onto itself. They refer, for example, to New Zealand and especially to the "success" of Australian multiculturalism. However, it seems that the relativist interpretation of multiculturalism has never found any official approval in Australia. Although, governments have adopted policies and programs to support cultural minorities, abandoning previous assimilatory practices - policies have been able to build and maintain a level of social cohesion in spite of increasing cultural diversity, recognizing minorities their right to maintain their own culture within the reference culture of the host society. The acknowledgement of group rights has been balanced with that of equal responsibility for sharing a core of fundamental values, such as gender equality, religious freedom, racial tolerance, as well as the commitment to learning English and job searching. Their applied model seems closer to the pluralist project than to the multicultural one.

In conclusion, multiculturalist policies should have made a difference, in those European countries where they were not formally implemented ${ }^{3}$. It seems that the recognition interpretation by Muslims does not lead where multiculturalist doctrines and policies promise. On the contrary, Sartori seems to have been correct (2000). Even more so, regarding the condition of communities that do not want to integrate, the multiculturalist model of group rights, without reciprocity, is not effective in producing social cohesion and peace, but seems to be able to maintain, favor and reinforce more radical, separatist tendencies.

\footnotetext{
${ }^{3}$ In France, for example, despite the 2006 awareness campaigns, it was estimated that in the Ile-de-France and in the six departments with the highest Islamic population, there were at least over 60 thousand teenagers from the age of ten to eighteen, threatened by forced marriages and 55 thousand Muslim children who risked infibulation (the trend seemed a constant compared to past years, Gams, Group for the Abolition of Sexual Mutilation, 2006). Although French law forbids forced marriages and prosecutes all those who practice infibulation to Muslims with French citizenship or to those having resident status, this trend seems to be growing. Italy is also a case in point: the number of cases of honor-based violence against Muslim women and second-generation youths have increased in recent years. Between 2010 and 2011, there were around 8,000 requests for help, with $82 \%$ of complaints sent to the association for the protection of the rights of Muslim women (mainly Moroccan women, according to the most significant Islamic presence in Ital, ACMID Donna, Five-Year Report, 2012). Likewise, the practice of Urfi marriages (marriages celebrated with Islamic rites in sheds or garages transformed into mosques) have created polygamy, illegal for the Italian state. In fact, this has led to an unexpectedly high number of polygamous marriages in Italy: despite the fact that they are legally prohibited, it was estimated that as far back as 2012, there were about 15 thousand (ACMID Donna, Five-Year Report, 2012).
} 


\section{From Multi-Culturalism to Inter-Culturalism}

The delineation of cultural diversity co-habitation strategies proceeds from the convictions that substantiate the response to the problems of integration and social cohesion strongly generated by globalization processes. Multiculturalist emphasis on ethnic roots, on identity construction wrapped up in the sure meshes of tradition networks and community ties, against an individualized modernity that has worn down, loosened and deformed the interweaving of the community fabric to the point of losing its ability for restrains the process of self-formation, has raised serious doubts regarding its ability to foster social cohesion and social integration. As we have seen, Multiculturalism itself risks creating a Balkanization of sociality, closed and reified cultures, separate groups destined to remain strangers, without sharing anything, without some sharing of value meanings on which integration and cohesion, social ties, communication and relationships between groups depend. In other terms, the problematic sufficiency of a procedural integration, without a moral foundation ensured by a platform, albeit minimal, of shared common values, risks, on the one hand, of amplifying the potential for social conflict, and, on the other, of establishing forms of social injustice, by maintaining, through group right, those cultural traditions that preside over possible intra-group discriminatory practices.

Reflections of this kind have opened different scenarios and provided alternative solutions.

The reference, for example, to the "community", after the exile in which modernity had confined it, can, Bauman has asked himself, imply the oblivion of the lesson of history? Can the virtues of the community be able to forgive everything to it, to forget everything, the prevaricating force of internal pressures, the propensity to ethnocentrism, to collective narcissism (Bauman, 1997)?

For Bauman (1999), the lesson of History itself shows us the risks inherent in communitarian multiculturalism and serves as support for a model of diversity management with a pluralist character. In this regard, Bauman does not recall any reasons other than those which, as we have seen, have conveyed the most widespread consensus. With a significant reference to Odo Marquand, in his Apologie des Zufälligen ${ }^{4}$ (Marquand, 1986), the reason is the same: the absolutistic status of the ideal of Good kept within the context of community living at its foundation, which ties its members into a single and stable whole (an absolute principle like the superiority of the race, one God, one party, History's one law), as device in creating cohesion and integration but also in violent conflicts perpetrated in the name of Truth, protected from any sense of responsibility and the

\footnotetext{
4"People killed or kill one another in disputes about the unambiguously correct interpretation of a book, namely, the Holy Scriptures" o "[...] of the one sole univocal world history. [...] If two human group $[\ldots]$ admit only one unique and solely correct interpretation, and that we and only we have this interpretation, then the result can be the hermeneutic homicide" (1991 [1986]: 103). In other words, by quoting Marquand, for Bauman, there is no atrocity that cannot be committed or that has not already been committed in the name of Truth, in the name of an ideal of Good preserved within community life (absolute principles such as the one God, the one party, the one law of history), devoid of any sense of both individual and collective responsibility and guilt.
} 
risk of being condemned by one's own conscience.

One cannot but recognize, for Bauman, that the openness toward dialogue encouraged by pluralism-the pluralizing hermeneutics of Marquand, the concordance on the part of all the contenders that a book can lend itself to different interpretations, always new and original, teaches, on the contrary, to lay down arms, to discolor the intransigence of the singularizing hermeneutics in the art of mutually negotiating meanings (quotations from Bauman, 1999: p. 13). In fact, Bauman challenges Community advocates to find in the History at the first cry of the human individual (Bauman, 1999: p. 15) any example of conflict, any act of inter or intra group cruelty perpetrated in the name of pluralism and pluralist tolerance In other words, for the Polish sociologist, the solution against fear of nihilistic danger that frightens the detractors of polytheism cannot reside in what, in the end, seems to him as an anachronistic leap back in time.

For Bauman, the solution is to be found in the de-reification of every cultural reification, in overcoming that emptiness, that deficit, as Donati called it (2008: p. 31) of relationality among cultures, established by the multiculturalist indifference towards traits of common symbolic language.

From a systemic point of view, a shared symbolic code, some shared beliefs (in terms of language, values, expectations, norms...) is the condition for the very constitution of social systems as communicative systems of interaction.

From this point of view, today, Interculturalism is proposed as new policy of governance of cultural differences (Cantle, 2015, 2016; Bouchard, 2011, 2015; Barrett, 2013; Guidikova, 2015; Zapata-Barrero, 2016, 2017). Interculturalism aims to promote social integration cohesion starting from two principles: the prevalence of "the individual", of his freedom of choice, on "the group", and the dynamic conception of culture. In so doing, it detaches from essentialist conception of multiculturalism both identity, according to which diversity must be interpreted only in terms of origin and culture, and culture, considered as rooted in territory (Barrett, 2013).

In this way, the social vision proposed by the intercultural model seems to obviate the limits of multiculturalism, encompassing the idea of forging a shared basis of values through a concept of reciprocity that, on one hand, incorporates that of pluralism (reciprocity oriented by liberal and democratic ethos that marks the culture of modern western societies) and on the other hand, "expands" it.

There is growing consensus today in believing that policies capable of creating greater inclusion, integration and social cohesion in poly-ethnic democracies are those that employ diversity management strategies, enucleated around a bi-directional or reciprocal adaptation process (Rodriguez-Garcia, 2010; Rattansi, 2011). This means aiming at the construction of a convivendi modus founded upon a sharing that derives from encounter and dialogue between identity differences. It is not a matter of erasing the differences (homogenizing assimilation or solution by subtraction), nor of crystallizing them, separating them, estrang- 
ing them, and ultimately opposing them (multiculturalist isolationism or solution by addition), but of encouraging all groups, including cultural majorities of the host society, to engage in a meaningful dialogue, aimed at a process of $\mathrm{mu}$ tual learning, capable of leading to unity from and of difference (Archer, 1991), to a world of common meanings, at the foundation of civilized life, rooted on a "solid ground of mutual understanding" (Donati, 2008: p. 60). This fusion of cognitive horizons (Horizontverschmelzung), one might say, is, as Gadamer teaches, a necessary condition for mutual understanding (Gadamer, 1960). Compared to pluralism, therefore, inter-culturalism insists on the possibility of mutual learning, recognizing that minority groups also have the right to propose changes to the host society, if it can be shown that these changes are in the best interest of the proposing cultural group and that they do not violate the rights of any other group (Rodriguez-Garcia, 2010; Cantle, 2016).

Inter-culturalism emphasizes the dialogic, processual nature of cultures, understood as not fixed static entities but dynamic process of constructing meanings, with others and through others. If conceiving multicultural society as a mosaic of fixed cultural identities can take on the connotation of a sociological and logical paradox, conceiving cultures as a process, and multicultural society as a "network of crossed identifications" (Baumann, 1999: p. 124), seems able to efface the paradoxes, to avoid the impasse in which communitarian or pluralist multiculturalism appears finally to stop.

To be precise, still today the relationship between interculturalism and multiculturalism constitutes the core of a debate which is very controversial. On the one hand, interculturalists emphasize a clear theoretical detachment of interculturalism from multiculturalism. Cantle contends interculturalism an opportunity to replace multiculturalism as conceptual and political framework (Cantle, 2012: p. 2) and Maxwell considers it a step forward compared to multiculturalism (Maxwell et al., 2012: p. 429). Cantle's critical arguments (2016) go in the direction already specified, that is, the multiculturalism tendency to close individual cultural identities in static and monolithic containers, to consider them not subjected to evolution and progress through dialogue and reason, linked to an fixed idea of culture in space and time, whose intrinsic dynamism, its fluid nature, every possibility for change and evolution, is denied. Cantle critically interprets the implications of this approach pointing out the multiculturalism tendency to erode the foundations of community cohesion and universality of human rights, the significant contribution that it gives to "parallel societies" genesis, to social balkanization rather than integration and cohesion, by its emphasis on identity policies. In turn, multiculturalism supporters reject these criticisms. Meer \& Modood (2012, 2016; see also Modood, 2015) come to argue that interculturalism is even just a variant, a particular version, a critical friend of normative multiculturalism, considering all its facets. According to Modood, having presented multiculturalism as a form of dialogical citizenship, intercultural dialogue is central to multiculturalism, even foundational to it (Modood, 2017, 
online). This same idea is shared also from Zapata-Barrero and Kymlicka (Zapata-Barrero, 2016, 2017; Kymlicka, 2016). Therefore, multiculturalism is still considered valid from a theoretical point of view as well as from a political point of view, although the need is recognized to revisit it by refining its conceptual framework in the direction of a clearer balance between unity and diversity, minority and majority (Modood, 2017; 2018b). Modood, for example, admits that multiculturalists, and himself, have not engaged much with the concept of majority and unity, although he contends that this concept is implicit in multiculturalism.

Beyond these particular positions, however, in general a conceptual difference between interculturalism and multiculturalism can be grasped. Although both approaches give importance to dialogue, the purpose theoretically assigned to it is different. Interculturalism frames the device of dialogue between different cultural identities in the context of integrations needs. Whereas multiculturalism insists on diversity and interventions aimed at its recognition, interculturalism gives greater importance to unity and interventions aimed at integration. On the one hand, multiculturalism, consistently, emphasizes the "multi", on the other hand, interculturalism, coherently, emphasizes the "inter" (Taylor, 2012), looking for a guideline for dialogue that guarantees unity.

In this regard, interculturalists, like Bouchard (2011; 2015), have been criticized for majority precedence principle (Modood, 2017).

However, from my perspective, as I will say below, the terms of the question seems to have been too simplified.

Taking up the lines of the discourse, sociologically speaking, compared to multiculturalism, which, in insisting on an equal respect for cultures, risks closing up groups and reifying cultures, interculturalism seems a quality leap to the extent that it promotes a process of dynamic integration, which refers to a $m u$ tual fertilization of cultures.

In this sense, inter-culturalism is configured as an interactive project of coexistence, in difference and with difference, and as a model of integration that assumes the need for a core of shared values, whose construction-here, as we said, lies its novelty-is conceived within a mutual learning process among cultures. This model refers to a new concept of collective and individual identity that of enriched identity (e.g. Samir Khalil, 2007; Paolucci, 2010, 2016). As Gerd Baumann clarifies, one passes from a dominant culture discourse to a demiotic discourse (Baumann, 1999), which affirms the cultural and spiritual identity that distinguishes the West, but enriches it with the other cultures of which the identity minorities are bearers, and vice versa. In this way, dynamics call all the involved parties in question: on the one hand, inter-culturalism implies the enhancement of one's cultural identity; on the other, it implies reciprocal willingness to acknowledge what can enrich it, always in the logic of a mutual encounter, dialogue and learning among different identities. In this context, the pre-eminent role entrusted to intercultural pedagogy is justified, or better still, to 
what Donati, in his proposal for managing differences, has called collecitive reflexivity, for the production of those merit goods worthy of being recognized and pursued as citizenship rights by the entire political community (Donati, 2008: p. 44). A central element in the process of intercultural incorporation would be a citizenship reformulation as a bottom-up citizenship, whereby equality at the structural level, the universal level of rights and obligations of citizenship, does not imply the disappearance of differences, but their coexistence in the public sphere, promoted by participation and civic engagement of all the actors involved in the socio-political process, in a public confrontation where semantic negotiation favors reciprocal learning among cultures.

Thus, on one hand, it is possible to build that enriched common base capable of forging bonds between groups and peaceful social cooperation. On the other hand, the intercultural solution responds to principles of social fairness, avoiding confusion between cultural freedom, fundamental for human dignity, and the defense of any form of cultural legacy that does not take into account the choices people would make if they had the opportunity of seeing things in a critical manner (Sen, 2006c).

In more analytical terms, we need to underline three qualifying aspects of the intercultural proposal which, from a sociological perspective, enable it to "make" society by combining cultural differentiation with the instance of integration and social cohesion.

The first aspect of inter-culturalism concerns the fact that it is articulated on the construction of a common sense tie which allows relationality and dialogue between groups, and a more certain basis for cohesion and integration. In this regard, the debate on the criteria that can direct dialogue, make it possible and, ultimately, leads it to a peaceful conclusion, is significant. Because dialogue is not a colloquy, at the end of which, everyone goes on his own way, with his own convictions left intact, but aspires to build a common world and an enriched identity, the inter-culture path has required, from the beginning, the need for serious reflection on the conditions capable of making a common world practicable. How can we build this common world? What dialogue, when the differences are often insurmountable? On what basis can we build a mutual understanding to which the dialogue among various cultures can be anchored? In other words, in order to dialogue on values, the need of supra-ordered, meta-cultural criteria has been recognized, to which everyone must refer, and which directs the dialogue itself. In this respect, inter-culturalism emphasizes the constraint of the compliance of every symbolic value to the inalienable principle of human dignity as a meta-cultural guiding criterion, allowing, regardless of any dogmatic beliefs, to discriminate between cultural differences that can be accepted and confirmed and those that cannot be part of a common world of symbolic meanings ( $\mathrm{Za}$ magni, 2002; Tibi, 2002; Donati, 2008).

Donati clarifies this point well (2008).

Placing the principle of human dignity as a super-ordained criterion, would 
allow reciprocal dialogue permitting a judgment of rationality on values that is independent of the culture in which they are embedded, conferring citizenship to values if and as far as they respond to what is worthy of human being, to dignity as a natural property of man as man, and, in this sense, as an autonomous criterion, which does not depend on any cultural specificity or dogmatic faith (Donati, 2008: p. 125). Public activation of a reflexive capacity of the rationality that is exercised on values, promoting those that favor a humanization of the relationship that they inform, in light of the criterion of respect for human dignity, would ensure, as a result of a participatory dialogic process, that mutual exchange of symbolic meanings likely to lead to a morphogenesis of the cultural identities involved, and to the formation of a common world, of a new laicity of culture and of the State, or, again, of that societarismo costituzionale, as Donati called it, capable of going beyond multiculturalism ${ }^{5}$, with its isolationist risks. Public adoption, therefore, of a relational paradigm would work to ensure the effective feasibility of the intercultural project, overcoming both multicultural isolationism and possible conflicts related to the institutional, coming from

\footnotetext{
${ }^{5}$ According to Donati, overcoming multiculturalism requires a theoretical revision of rationality, i.e. a conceptualization that expands rationality beyond its classical dimensions, both from the still too restrictive functionalist Durkheimian conception and from the Weberian conception, overcoming the idea that values cannot be judged when they are the expression of a common feeling. In more specific terms, in Donati's perspective, given that each culture differs according to the effects that its symbolic values produce in the relationship they inform, the recognition of cultural diversity (accepted and confirmed rather than rejected and dismissed) emanates from exercise of a public reason applied to relationships. This is a reflexive faculty that evaluates rationality (the good reasons) of any culture, relating this rationality judgment not only to its content of instrumental rationality (of means) or of situated purpose or of relational normativity, but to its ultimate sense of conformity to what is worthy of human being to that which, as such, is inalienable, non-negotiable, that is, to its content of symbolic rationality (rationality exercised on values) or rationality of dignity (Donati, 2008: p. 109). What matters, therefore, is whether or not certain symbolic values produce a humanization growth of the individuals involved in relationships that values orient. Following this line of reasoning, for example, according to our author, we can recognize infibulation, polygamy, repudiation, arranged marriages, the relationship between man and woman marked by various forms of social and legal discrimination against women, and why not Islamic veil, as irrational practices, as well as the Barbagia code that legitimizes revenge. And this is not because these practices violate human rights-an all-Western conception, on which, therefore, identity conflicts are triggered-but because, explains Donati, they are lacking to produce a growth of humanization of the woman, of her dignity as proper characteristic (property) of the human (ibid). It is thus, through reflexive rationality, that it is possible to activate a mutual exchange of symbolic meanings capable of leading to a morphogenesis of the cultural identities involved and to the formation of a common world, of a new State and culture laicity, which confers cultural citizenship to values if and as they respond to what is worthy of the human individual, regardless of justifications based on faith. The adoption, therefore, of what Donati called a relational paradigm ensures the effective feasibility of the intercultural project for the foundation of that societarismo costituzionale where the overcoming of multiculturalist isolationism is identified. Following a similar line of reasoning, Zamagni (2002) emphasizes the need for a society which in its construction, by establishing the principles and norms of social life, assumes the dignity of the human person as an indispensable and universal criterion. Faced with multiple and different cultures, the proposal, thus, becomes that of a transcultural coexistence project, as the author prefers to call it, where, regardless of particular cultural roots, in considering a given culture it appears binding to distinguish what is tolerable from what is respectable and what is shareable, firmly anchoring each of the three levels of judgment onto the condition of the protection of human dignity as a principle that, even though the West first conceptualized it, cannot however, for Zamagni, only be limited to Western societies.
} 
above, determination of a recognition threshold.

Therefore, if individual cultural specificities are allowed the recognition of the right to preserve their own identity, inter-culturalism institutionalizes this recognition within parameters of the culture of human dignity as a reference culture (or Leitkultur, as Bassam Tibi calls it, 2002) which, although it finds its codification in European Constitutions, is established as a meta-cultural heritage, independent of hegemonic national connotations, able, precisely for this reason, to ensure the possibility of intercultural dialogue and conflict composition.

The second aspect of inter-culturalism concerns the meaning by which the concept of reciprocity is to be understood. What is still to be underlined is that intercultural reciprocity is comprehended within the framework of a fertilization of the cultural identities involved, as a result of a participatory dialogic process. Therefore, it is not just a question of bi-directionally correcting unilateral recognition relationship from majorities to the minorities, so as to obviate the consequences of dis-integration already highlighted. Bi-directionality is not limited and does not end with proposals of civic education programs, as is widely discussed in politics in various European contexts. It goes further, to the more proper meaning of reciprocity, completing the path of recognition in terms of a circular relational process open to a possible morphogenesis of all the identities involved in the relational circuit (majorities and minorities).

Therefore, the benefits of the inter-cultural approach would reverberate over all the parties involved. Reciprocity oriented by human dignity would act as a catalyst for positive changes within different cultures: for minority cultures, mutual comparison could be an incentive to open up to liberal and democratic values, and, for post-modern Western societies it could act as an incentive to revisit certain extremisms of individualization and secularization process that marks them (see Marzano, 2002: p. 272).

The third qualifying aspect of the inter-culturalist integration model is a new understanding of the concept of secularism or laicism. In this sense, while it does not question the secular nature of the State in the sense of its neutrality with respect to religion, the intercultural model enhances the relational resource of different religious expressions which occupy and which are destined to occupy the Western public sphere more and more permanently at the dawn of the third millennium, recognizing their inclusion in the public debate sphere, sphere that, however, remain secular as far as it always keeps firm reference to respect for human dignity as a principle of reason, regardless of considerations related to dogmas of faith

In other words, the intercultural model operates using a concept of laicity understood as an open secularism, in the sense of a condition of the public sphere that sees religious expressions no longer excluded from the common discourse space. The area of secularism should, therefore, be mainly concerned with the criterion of reason which must preside over dialogue in the public sphere. Dialogue between the different religious expressions is subject to a criterion of 
mutual "moderation" between faith and reason (see Donati, 2002). This reciprocal "moderation" function appears thus, to be the keystone of all intercultural discourse, which enables overcoming the limits of assimilationist models, on the one hand, and the problems of ethical relativism involved in multiculturalist ideology, on the other, achieving integration, new order with coherence.

Some empirical attempts at inter-culturalism have been exemplified by the Canadian debate on the Shari'a Laws, held in 2005 in Ontario. At this time, the Islamic Institute of Civil Justice proposed the creation of arbitration boards based on Islamic religious law to resolve family law disputes. This led to public debate between supporters of religious rights and supporters of women's rights among traditionalist Muslim community members and other social parts, non-Muslim women and men, as well as the secular and liberal part of the Muslim community. This debate ended with the prohibition of all forms of arbitration based on religion and, in fairness, with the application of this prohibition to all religious groups. This result was obtained through public discussion and peaceful negotiation processes among all the different groups involved, oriented by the rule of respect for the dignity and freedom of women, prevailing both on the criterion of equal individual culture respect and on public space secularity established on principle.

The above Canadian case shows how other tricky issues in the West could find appropriate solutions as well, such as, for example, the issue of the head veil for Muslim women, an extremely controversial question since 1989, when some Muslim students were removed from the Creil school in France, because they entered the school wearing their traditional veil over their head. In France, this episode ended with an official veil prohibition in public places. Yet, this same controversy continues and has spread to other European countries that are now facing a growing Islamic territorial presence. The controversy lies in the fact that the prohibition is usually justified by appealing to Secular State principle. However, the ban has stirred up, as in the case of France, systematic criticism of assimilationism and cultural discrimination from Muslim minority. At this level, the question seems bound to constitute, as it has indeed, a perennial source of cultural conflict and identity controversy. Instead, a public debate, constrained to appeal to secular, super-ordinate, principle of human dignity respect, having to take into account the protection of those women who do not freely choose to wear the veil as a symbol of their religious and cultural identity but undergo this practice, often indicative of a state of social submission, seems better to dissolve the tangles that induce identity conflicts. This debate invokes a more convincing reason for the limitation of public tolerance towards veil practice, like what happened in the case of Islamic arbitral tribunal recognition refusal in Canada. The principle is always that of not wronging human dignity, a principle invoked today, however, by many secular Muslim feminists, in considering manifestations of tolerance on the use of the veil as well as the propensity to accept the requests in this sense oriented by Islamic feminists expressive of a naive multi- 
culturalism (Tamzali, 2010).

\section{Conclusion}

It is clear that the problem of harmonizing potentially conflicting demands, such as respect for diversity, peace, justice, social cohesion and social integration does not depend much, or only upon the number and degree of diversity between cultures that inhabit our democratic societies. The question is, primarily, a problem of management strategy of differences. In modern poly-ethnic democracies, it would be anachronistic to ignore the need to enhance the link between cultural freedom and cultural belonging. The notion that social cohesion and civic equality must require cultural homogeneity is, nowadays, hardly a sustainable idea, for the same reason that an "ossified humanity", that is, a culture not being a process, was already inconceivable to Lévi-Strauss in his Race et Histoire (1952). From this point of view, if so, we could not blame those who, as Young, raise doubts about whether integration is always desirable, or whether the more integrated a society is, the better, proposing to treat integration with caution (Mason, 2018). But if the idea of cultural homologation is unsustainable in an era of super-diversity, so is separation, estrangement of cultures that find themselves sharing the same social spaces. Separation, the enclosure in communities of similar people, in real islands of uniformity, as Bauman called them, either one imposed from above or the one in which the multiculturalist dream seems to shatter, is not the right device to ensure cohesion and integration-peaceful coexistence and social cooperation. Fundamentalist tendencies, the various isms of the world to which History has accustomed us, with concentration camps and lagers, ethnic cleansing, enslavement, shahids of militant neo-asceticism, rampant Christian phobias and gender oppression, mixophobic and xenophobic tendencies, fear of cultural diversity within its gated communities (Bauman, 2005), estrangement and mutual opposition between us and them with its cultural ghettos (it does not matter whether they are imposed or even wanted by individuals who want to remain separated), are nourished whenever cultures are essentialized, reified and the impossibility of mutually engaging in meaningful communication, in an intimate and profound way, in a human way, as Sennett would say (1996), manifests. Therefore, it seems unrealistic to think that a new positive cohabitation can arise from the salad bowl model.

This paper reaches this conviction showing perplexities on the sufficiency of procedural foundations as social integration constraint able of "making society" between us and them, and, consequently, on the identity policy proposed by normative multiculturalism.

Although some sociological theorizations consider that, today, in complex, extremely differentiated, individualized and detraditionalized societies such as our modern society, sic et simpliciter adhesion to norm is the only possibility of social system integration (as we said, Luhmann, for example, believes that integration in complex societies has nothing to do with consensus), this strategy 
risks amplifying differences rather than forming unity, even without eliminating diversities, and fragilizing social ties (for example, this is what we can observe for social systems such as family or couple relationships, when living together becomes a pure bureaucratic issue and the very meaning of relational tie has evaporated). In this sense, the sufficiency of procedural foundations should require the need of a Hobbesian state. As we said, the perplexities increase if we look at the issue from the perspective of the New Systems Theory.

From my point of view, Complexity completes the interpretative framework.

If it is true that systems are an interweaving of constraints and emergencies, and that they are able to self-organize, to survive by forming new integrative constraints, and not to get lost into chaos only if they are in an intermediate position between connection and differentiation, neither too connected nor too differentiated, irrelated and erratic, disordered to the point of no longer finding forms of internal organization, starting from this assumption, and for what has already been said, procedural foundations as device of integration and normative multiculturalism that emphasizes it show serious limits.

From this point of view, normative multiculturalism risks to be a society project that exacerbates differentiation, breaking society into separate, unrelated, foreign groups, and bringing it to find with difficulty, in the absence of reciprocity, of an albeit minimal platform of shared values, cohesion and integration. The type of society that multiculturalism proposes seems that of a society designed to reach a state of maximum differentiation, incapable of balancing differentiation and connection, disordered, no longer "system", that is, that state of irrelation between different, culturally connoted members, which should be avoided by systems, any system, natural or social, identifying itself with the limit of order and governability.

From an empirical point of view, in contexts that are oriented towards the policies of identity, albeit in a more or less faithful way to the doctrine of multiculturalist models, without making enough attention to reciprocity, some signs which show dissonance with respect to the multiculturalist premises and promises of ensuring social cohesion and peace, seem to lead to seriously consider this risk. The many forms of Islamic radicalism, the many populisms, the many signs of xenophobia and nationalist extremism, seem to constitute the disturbing signs of that differentiation excess, of that short-circuit of relationships among cultural groups, effective to separate, estrange and oppose them, that normative multiculturalism, as it has been formulated, institutionalizes.

Just in the context of Complexity, the reference to inter-cultualism, as new governamentality approach for living together, in "difference" and with differences, not side by side, as equals in dignity, can gain a deeper sense.

Against the backdrop of old and always renewed dilemmas of a difficult reconciliation between community and individual, freedom and belonging, Faith and Reason, tradition and modernity, inter-culturalism shows potentialities that go beyond the limits shown by the previous formulas,, avoiding, on the one 
hand, mono-culturalism risks, and, on the other hand, that social balkanization that not resolve conflicts but rather compromises peace and social integration.

In conclusion, taking into account, on the one hand, the need to form a national liberal conscience as underlying condition for the recognition of individual universal rights, through scholastic and juridical inclusion, and, on the other hand, the need of a cautious recognition of collective rights that is not only established on principle, against any evaluation whatsoever (in fact, one thing is recognition of places of worship or special cemetery departments, recognition of significant religious festivity and work permits for worship practices, support for food codes and practices of slaughtering animals, another thing is the recognition of faith schools or of Sharia courts), inter-culturalism allows us to reconcile integration, cohesion and diversity, by repairing the relational short-circuit among identity differences where implicit essentialism and axiological relativism of the multiculturalist integration model lands. And it can do so, not merely because it admits the creation of civic, public, dialogic space, but above all because it anchors the possibility and resolution of dialogue to that criterion of mutual compliance to the inalienable trans-cultural principle of human dignity that comes first, before any reason without faith, that impoverishes and empties reason itself of any humanism, and before any faith that prevails on reason and discolors it into violence. By this criterion orienting dialogue, balancing the relationships, we can try to lay the foundations for good praxis and good multi-ethnic society.

\section{Conflicts of Interest}

The authors declare no conflicts of interest regarding the publication of this paper.

\section{References}

Alexander, J. C. (2001). Theorizing the "Modes of Incorporation": Assimilation, Hyphenation, and Muticulturalism as Varieties of Civil Participation. Sociological Theory, 19, 237-249. https://doi.org/10.1111/0735-2751.00139

Alexander, J. C., \& Thompson, K. (2008). A Contemporary Introduction to Sociology, Culture, and Society in Transition. Boulder: Paradigm Publishers.

Archer, M. S. (1991). Sociology for One World: Unity and Diversity. International Sociology, 6, 131-147. https://doi.org/10.1177/026858091006002001

Barrett, M. (2013). Interculturalism and Multiculturalism: Similarities and Differences. Strasbourg: Council of Europe Publishing.

Barry, B. (2001). Culture and Equality: An Egalitarian Critique of Multiculturalism. Cambridge: Polity Press.

Baubock, R. (1996). Social and Culture Integration in a Civil Society. In R. Baubock, A. Heller, \& A. Zolberg (Eds.), The Challenge of Diversity. Integration and Pluralism in Societies of Immigration (pp. 67-133). Vienna: Avebury.

Baubock, R. (2004). The Civic Citizenship-A New Concept for the New Europe. In R. Sussmuth, \& W. Weidenfeld (Eds.), Managing Integration: European Union Responsi- 
bilities towards Immigrants (pp. 146-163). Brussels: Bertelsmann Foundation.

Bauman, Z. (1997). The Making and Unmaking of Strangers. In Z. Bauman (Eds.), Postmodernity and Its Discontents (pp. 17-34). Oxford: Blackwell.

Bauman, Z. (1999). La società delP incertezza. Bologna: Il Mulino.

Bauman, Z. (2000). Liquid Modernity. Cambridge: Polity Press.

Bauman, Z. (2001). Community. Seeking Safety in an Insecure World. Cambridge: Polity Press.

Bauman, Z. (2004). Identity. Conversations with Benedetto Vecchi. Cambridge: Polity Press.

Bauman, Z. (2005.). Fear, Security and City. Living with Strangers. Cambridge: Polity Press.

Bauman, Z. (2013). Communitas. Uguali e diversi nella società liquida. Conversations with Carlo Bordoni (a cura di Carlo Bordoni), Aliberti Editore, Reggio Emilia.

Baumann, G. (1999). The Multicultural Riddle: Rethinking National, Ethnic and Religious Identities. New York: Routledge.

Beck, U. (1997). What Is Globalization. Cambridge: Polity Press.

Benhabib, S. (2002). The Claims of Culture: Equality and Diversity in the Global Era. Princeton: Princeton University Press.

Bouchard, G. (2011). What Is Interculturalism? McGill Law Journal-Revue de droit de McGill, 56, 435-468.

Bouchard, G. (2015). Interculturalism. A Vision from Quebec. Toronto: University of Toronto Press.

Boudon, R. (1999). Valori e Morale: Le Ragioni della Ragione. Biblioteca della libertà, 150, 21-46.

Brubaker, R. (2001). The Return of Assimilation? Changing Perspectives on Immigration and Its Sequels in France, German and United States. Ethnic and Racial Studies, 24, 531-548. https://doi.org/10.1080/01419870120049770

Cantle, T. (2012). Interculturalism: The New Era of Cohesion and Diversity. Basingstoke: Palgrave Mcmillan. https://doi.org/10.1057/9781137027474

Cantle, T. (2015). Interculturalism: "Learning to Live in Diversity". In M. Antonisch (Eds.), Interculturalism versus Multiculturalism-The Cantle-Modood Debate, Ethnicities (pp. 2-10). https://doi.org/1177/1468796815604558

Cantle, T. (2016). The Case for Interculturalism, Plural Identities and Cohesion. In N. Meer, T. Modood, \& R. Zapata-Barrero (Eds.), Multiculturalism and Interculturalism: Debating the Dividing Lines (pp. 133-157). Edinburgh: Edinburgh University Press.

Cantle, T., \& The Community Cohesion Team (2001). Community Cohesion: A Report of the Independent Review Chaired by Ted Cantle. London: Government Printing Office.

Carens, J. (2000). Culture, Citizenship and Community. New York: Oxford University Press. https://doi.org/10.1093/0198297688.001.0001

Colombo, E. (2002). Le società multiculturali [Multicultural Societies]. Milano: Franco Angeli.

Condorelli, R. (2016). Complex Systems Theory. Some Considerations for Sociology. Open Journal of Applied Sciences, 6, 422. https://doi.org/10.4236/ojapps.2016.67044

Crespi, F. (1994). Imparare ad esistere. Nuovi fondamenti della solidarietà sociale. Roma: Donzelli Editore. 
Donati, P. (2002). Pensare la società civile come sfera pubblica religiosamente qualificata. In C. Vigna, \& S. Zamagni (Eds), Multiculturalismo e Identità (pp.51-107). Milano: Vita e Pensiero.

Donati, P. (2008). Oltre il multiculturalismo. Roma: Editori Laterza.

Entizinger, H. (2003). The Rise and Fall of Multiculturalism: The Case of the Netherland. In C. Joppke, \& E. Morawska (Eds.), Towards to Assimilation and Citizenship (pp 59-86). Basingstoke: Palgrave Macmillan.

Etzioni, A. (1995). New Communitarian Thinking. Persons, Virtues, Institutions, and Communities. Virginia: University Press of Virginia.

Faas, D. (2008). Constructing Identities: The Ethno-National and Nationalistic Identities of White and Turkish Students in Two English Secondary Schools. British Journal of Sociology of Education, 29, 37-48. https://doi.org/10.1080/01425690701737440

Foreign Policy Centre Chicago Cultural Studies Group (1994). Critical Multiculturalism. In D. T. Goldberg (Ed.), Multiculturalism: A Critical Reader (pp. 114-140). Oxford: Blackwell.

Gadamer, H. G. (1960). Wahrheit und Method [Truth and Methode]. Tübingen: Mohr Siebeck.

Giroux, H. A. (1994). Insurgent Multiculturalism and the Promise of Pedagogy. In D. T. Goldberg (Ed.), Multiculturalism: A Critical Reader (pp. 325-344). Oxford: Blackwell.

Glazer, N. (1970). Beyond the Melting Pot. Cambridge: Massachusetts Institute of Technology Press.

Glazer, N. (1997). We Are All Multiculturalists Now. Cambridge: Massachusetts Harvard University Press.

Grillo, R. (2005). Backlash against Diversity? Identity and Cultural Politics in European Cities. Oxford: Centre on Migration, Policy and Society [COMPAS] Working Paper WP-05-14.

Grillo, R. (2007). An Excess of Alterity? Debating Difference in a Multicultural Society. Ethnic and Racial Studies, 6, 979-998. https://doi.org/10.1080/01419870701599424

Guidikova, I. (2014). Cultural Diversity and Cities-Intercultural Integration approach. Fiesole: EUI RSCAS Policy Paper.

Guidikova, I. (2015). Intercultural Integration: A New Paradigm for Managing Diversity as an Advantage. In R. Zapata-Barrero (Ed.), Interculturalism in Cities. Concept, Policy, and Implementation (pp. 136-151). London: Edward Elgar Publishing. https://doi.org/10.4337/9781784715328.00015

Guolo, R. (2004). L'Islam è compatibile con la democrazia? Roma: Editori Laterza.

Habermas, J. (1996). Kampf um Anerkennung im demokratischen Rechtsstaat. Frankfurt am Main: Suhrkamp Verlag.

Hall, S. (2000). Conclusion: The Multicultural Question. In B. Hesse (Ed.), Unsettled Multiculturalisms. Diasporas, Entanglements, Transruptions (pp. 209-241). London: Zed Books. https://doi.org/10.5949/liverpool/9780853235866.003.0006

Hall, S. (2001). The Multicultural Question. Milton Keynes, UK: Pavis Centre for Social and Cultural Research, Open University Press.

Hart, K. (2005). The London Bombing: The Crisis for Multiculturalism? Anthropology Today, 21, 1-2. https://doi.org/10.1111/j.0268-540X.2005.00378.x

Hartmann, D., \& Gerteis, J. (2005). Dealing with Diversity: Mapping Multiculturalism in Sociological Terms. Sociological Theory, 23, 218-240.

https://doi.org/10.1111/j.0735-2751.2005.00251.x 
Hedetoft, U. (2010). Denmark versus Multiculturalism. In S. Vertovec, \& S. Wessendorf (Eds.), The Multiculturalism Backlash: European Discourses, Policies and Practices (pp. 111-130). London and New York: Routledge.

Heller, A. (1996). The Many Faces of Multiculturalism. In R. Baubock, A. Heller, \& A. Zolberg (Eds.), The Challenge of Diversity. Integration and Pluralism in Societies of Immigration (pp. 25-43). Vienna: Avebury.

Home Office (2000). A Choice by Right. London. Government Printing Office.

Honneth, A. (1992). Kampf un Anerkennung. zur moralischen Grammatik sozialer Konfliktc [ The Struggle for Recognition]. Frankfurt: Suhrkamp.

IKWRO. (2011). Nearly 3000 Cases of "Honour" Violence Every Year in the UK. http://ikwro.org.uk

IKWRO. (2015). Annual Report 2014-2015-Honour based violence (HBV), Forced Marriage. http://ikwro.org.uk

Joppke, C. (2004). The Retreat of Multiculturalism in the Liberal State: Theory and Policy. British Journal of Sociology, 55, 237-257. https://doi.org/10.1111/j.1468-4446.2004.00017.x

Kepel, G. (2005). Europe’s Answer to Londonistan. Open Democracy. http://www.opendemocracy.net/conflict -terrorism/londonistan_2775.jsp

Korteweg, A. (2006). The Murder of Theo Van Gogh: Gender, Religion and the Struggle over Immigrant Integration in the Netherland. In M. Bodemann, \& G. Yurdakul (Eds.), Migration, Citizenship, and Ethnos (pp. 147-166). New York: Palgrave Macmillan. https://doi.org/10.1057/9781403984678_8

Kundnami, A. (2002). The Death of Multiculturalism. Race \& Class, 43, 67-72. https://doi.org/10.1177/030639680204300406

Kymlicka, W. (1995b). The Rights of Minorities Cultures. Oxford: Oxford University Press.

Kymlicka, W. (2010). The Rise and Fall of Multiculturalism? New Debates on Inclusion and Accommodation in Diverse Societies. In S. Vertovec, \& S. Wessendorf (Eds.), The Multiculturalism Backlash: European Discourses, Policies and Practices (pp. 32-50). London and New York: Routledge. https://doi.org/10.1111/j.1468-2451.2010.01750.x

Kymlicka, W. (1995a). Multicultural Citizenship. Oxford: Oxford University Press.

Kymlicka, W. (2016). Defending Diversity in an Era of Populism: Multiculturalism and Interculturalism Compared. In N. Meer, T. Modood, \& R. Zapata-Barrero (Eds.), Multiculturalism and Interculturalism: Debating the Dividing Lines (pp. 158-177). Edinburgh: Edinburgh University Press.

Kymlicka, W. (2018). Liberal Multiculturalism as a Political Theory of State-Minority Relations. Political Theory, 46, 81-91. https://doi.org/10.1177/0090591717696021

Lasch, C. (1985). The Minimal Self. Psychic Survival in Troubled Time. London: Pan Books.

Lévi-Strauss, C. (1952). Race et Histoire [Race and History]. Paris: UNESCO.

Luhmann, N. (1981). Wie ist soziale Ordung moglich? Framkurt am Main: Suhrkamp Verlag.

Luhmann, N. (1984). Soziale Systeme [1995. Social Systems. Stanford. Stanford University Press]. Frankfurt an Main: Suhrkamp.

Lust, S. (2008). Abschied von Multikulti: Wege aus der Integrationskrise. Munich: Resch-Verlag.

Macfarlane, A. (2014). Female Genital Mutilation in England and Wales. London: City 
University London.

MacIntyre, A. (1981). After Virtue. London: Bloomsbury Academic.

Malik, K. (2014). Multiculturalism and Its Discontents: Rethinking Diversity after 9/11. London: Seagull Books.

Manij, I. (2004). The Trouble with Islam Today: A Muslim's Call for Reform in Her Faith. New York: St. Martin's Press.

Marquand, O. (1986). Apologie des Zufälligen: Philosophische Studien. Reclam: Stuttgart. [1991. In Defense of the Accidental. Oxford: Oxford University Press].

Marzano, F. (2002). Flussi migratori, sviluppo economico e coesistenza culturale. In C. Vigna, \& S. Zamagni (Eds), Multiculturalismo e Identità (pp. 263-273). Milano: Vita e Pensiero.

Mason, A. (2018). The Critique of Multiculturalism in Britain: Integration, Separation and Shared Identification. Critical Review of International Social and Political Philosophy, 21, 22-45. https://doi.org/10.1080/13698230.2017.1398444

Maturana, H., \& Varela, F. G. (1984). El arbol del conocimiento. [The Tree of Knowledge]. Santiago: Editorial Universitari.

Maxwell, B., Waddington, D. I., McDonough, K., \& Cormier, A. A. (2012). Interculturalism, Multiculturalism, and the State Funding and Regulation of Conservative Religious Schools. Educational Theory, 62, 427-447. https://doi.org/10.1111/j.1741-5446.2012.00455.x

McGhee, D. (2005). Intolerant Britain? Hate, Citizenship, and Difference. Milton Keynes, UK: Open University Press.

McGhee, D. (2008). The End of Multiculturalism? Terrorism, Integration and Human Rights. Maidenhead: Open University Press.

Meer, N., \& Modood, T. (2009). The Multicultural State Were in: Muslims, "Multiculture", and the "Civic-Rebalancing" of British Multiculturalism. Political Studies, 57, 473-497. https://doi.org/10.1111/j.1467-9248.2008.00745.x

Meer, N., \& Modood, T. (2012). How Does Interculturalism Contrast with Multiculturalism? Journal of Intercultural Studies, 33, 175-196. https://doi.org/10.1080/07256868.2011.618266

Meer, N., \& Modood, T. (2013). Contemporary Citizenship and Diversity in Europe. The place of Multiculturalism. In R. Taras (Ed.), Challenging Multiculturalism: Managing Diversity in Europe (pp. 24-51). Edinburgh: Edinburgh University Press.

Meer, N., \& Modood, T. (2015). Migration and Cultural Diversity Challenges in the 21st Century. In A. Triandafyllidou (Ed.), Routledge Handbook on Immigrant and Refugee Studies (pp. 180-190). London: Routledge.

Meer, N., \& Modood, T. (2016). Interculturalism, Multiculturalism and Citizenship. In N. Meer, T. Modood, \& R. Zapata-Barrero (Eds.), Multiculturalism and Interculturalism: Debating the Dividing Lines (pp. 27-52). Edinburgh: Edinburgh University Press.

Modood, T. (2007/2013). Multiculturalism: A Civic Idea. Oxford: Polity Press. https://doi.org/10.1002/9781405165518.wbeosm129

Modood, T. (2010). Still Not Easy Being British: Struggles for a Multicultural Citizenship. London: Trentham Books.

Modood, T. (2011). Post-Immigration Difference and Integration: The Case of Muslims in Western Europe. London: The British Academy.

Modood, T. (2015). What Is Multiculturalism and What Can It Learn from Interculturalism? In M. Antonisch (Ed.), Interculturalism versus Multiculturalism: The Can- 
tle-Modood Debate, Ethnicities (pp. 11-20). https://doi.org/1177/1468796815604558

Modood, T. (2017). Must Interculturalists Misrepresent Multiculturalism? Comparative Migration Studies, 5, 15. https://doi.org/10.1186/s40878-017-0058-y

Modood, T. (2018a). Equality for Secular Belief and Minority Faiths? Reflections on the Commission on Religion in British Public Life. In J. Walters, \& E. Kersley (Eds.), Religion and the Public Sphere: New Conversations (pp. 38-50). London: Routledge.

Modood, T. (2018b). The Continuing Relevance of a Concept of Multiculturalism. In Bertelsmann Stiftung (Ed.), Living Diversity—Shaping Society (pp. 131-146). Gütersloh: Verlag Bertelsmann Stiftung.

Morin, E. (1977). La Méthode. I. La nature de la nature [Method. Vol. I. toward a Study of Humankind]. Paris: Le Seuil.

Morin, E. (2008). On Complexity. Advances in Systems Theory, Complexity, and the Human Sciences. Cresskill, NJ: Hampton Press.

Murray, G. (2006). France: The Riots and the Republic. Race \& Class, 47, 26-45. https://doi.org/10.1177/0306396806063856

Okin, S. M. (1999). Is Multiculturalism Bad for Women? Princeton: Princeton University Press.

Paolucci, G. (2010). Immigrazione. Un problema o una risorsa? La sfida della convivenza nel segno delP identità arricchita. Monopoli, BA: Viverein.

Paolucci, G. (2016). Migranti, la sfida dell incontro. Castel Bolognese: Itaca.

Phillips, A. (2007). Multiculturalism without Culture. Princeton: Princeton University Press.

Prigogine, I., \& Nicolis, G. (1977). Self-Organization in Non-Equilibrium Systems. From Dissipative Structures to Order through Fluctuations. New York: Wiley.

Prigogine, I., \& Stengers, I. (1979). La Nouvelle Alliance. Metamorphose de la Science. Paris: Gallimard.

Prins, B., \& Saharso, S. (2010). From Toleration to Repression: The Dutch Backlash against Multiculturalism. In S. Vertovec, \& S. Wessendorf (Eds.), The Multiculturalism Backlash: European Discourses, Policies and Practices (pp. 72-92). London and New York: Routledge.

Putnam, R. (2007). E pluribus Unum: Diversity and Community in the Twenty-First Century. Scandinavian Political Studies, 30, 137-174.

https://doi.org/10.1111/j.1467-9477.2007.00176.x

Rattansi, A. (2011). Multiculturalism: A Very Short Introduction. Oxford: Oxford University Press. https://doi.org/10.1093/actrade/9780199546039.001.0001

Rawls, J. (1971). A Theory of Justice. Cambridge: Belknap Press of Harvard University Press.

Rodriguez-Garcia, D. (2010). Beyond Assimilation and Multiculturalism: A Critical Review of the Debate on Managing Diversity. Journal of International Migration and Integration, 11, 251-271. https://doi.org/10.1007/s12134-010-0140-x

Rosati, M. (2001). La solidarietà nelle società complesse. In F. Crespi, \& S. Moscovici (Eds.), Solidarietà in questione (pp. 16-82). Roma: Meltemi.

Rusconi, G. E. (1996). Multiculturalismo e cittadinanza democratica. Teoria Politica, 3, $17-22$.

Samir Khalil, S. (2001). Le Teorie Multiculturali Danneggiano gli Immigrati. La Repubblica, 20 aprile, 2001. 
Samir Khalil, S. (2007). Il caso Olanda insegna:serve una identità arricchita. Avvenire, 6 febbraio 2007.

Sandel, M. (1982). Liberalism and the Limits of Justice. New York: Cambridge University Press.

Sartori, G. (2000). Pluralismo, multiculturalismo ed estranei. Milano: Rizzoli.

Sbai, S. (2010). L'Inganno. Vittime del Multiculturalismo. Siena: Cantagalli.

Scheffer, P. (2001). Das multikulturelle Drama. Frankfurter Allgemeine Zeitung, 21 July.

Schlesinger, A. (1992). The Disuniting of America; Reflections on a Multicultural Society. New York: Norton.

Schönwälder, K. (2010). Germany: Integration Policy and Pluralism in a Self-Conscious Country of Immigration, in S. Vertovec, \& S. Wessendorf (Eds.), The Multiculturalism Backlash: European Discourses, Policies and Practices (pp.152-170). London and New York: Routledge.

Sen, A. (2000). La ragione prima dell'identità. In La ricchezza della ragione (pp. 3-29). Bologna: Il Mulino. [1999. Reason before Identity. Oxford: Oxford University Press.]

Sen, A. (2006a). Usi ed abusi del multiculturalismo. Corriere della sera, 23 febbraio 2006.

Sen, A. (2006b). Integrazione, la crisi del multiculturalismo. Corriere della sera, 23 agosto 2006.

Sen, A. (2006c). Identity and Violence: The Illusion of Destiny. London: Pinguin.

Sennett, R. (1996). The Uses of Disorder. Personal Identity and City Life. London: Faber \& Faber.

Shachar, A. (2001). Multicultural Jurisdictions. Cultural Differences and Women Right's. Cambridge: Cambridge University Press. https://doi.org/10.1017/CBO9780511490330

Shohat, E., \& Stam, R. (1994). Unthinking Eurocentrism: Multiculturalism and the Media. New York: Routledge.

Silberman, R., Alba, R., \& Fournier, I. (2007). Segmented Assimilation in France? Discrimination in the Labour Market against the Second Generation. Ethnic and Racial Studies, 30, 1-27. https://doi.org/10.1080/01419870601006488

Simon, P., \& Sala Pala, V. (2010). We're Not All Multiculturalists Yet: France Swings between Hard Integration and Soft Anti-Discrimination. In S. Vertovec, \& S. Wessendorf (Eds.), The Multiculturalism Backlash: European Discourses, Policies and Practices (pp. 92-111). London and New York: Routledge.

Slack, J. (2006). Why the Dogma of Multiculturalism Has Failed in Britain. Daily Mail 7 July.

Tamzali, W. (2010). El burka como excusa. Terrorismo intellectual, religiosa y moral contra la libertad de las mujeress. Barcelona: Saga Editorial.

Taylor, C. (1992). The Politics of Recognitio. Princeton: Princeton University Press.

Taylor, C. (2012). Interculturalism or Multiculturalism? Philosophy and Social Criticism, 38, 413-423. https://doi.org/10.1177/0191453711435656

Tibi, B. (2002). Islamische Zuwanderung. Die gescheiterte Integration. Munchen: Deutsche Verlags-Anstalt GmbH.

Touraine, A. (1998). Can We Live Together, Equal and Different? European Journal of Social Theory, 1, 165-178. https://doi.org/10.1177/136843198001002002

Touraine, A. (2011). Multiculturalismo. Perchè è andato in crisi il sogno della convivenza. La Repubblica, 10 febbraio.

Turner, T. (1993). Anthropology and Multiculturalism: What Is Anthropology that Mul- 
ticulturalists Should Be Mindful of It? Cultural Anthropology, 8, 411-429. https://doi.org/10.1525/can.1993.8.4.02a00010

Vasta, E. (2007). From Ethnic Minorities to Ethnic Majority Policy; Multiculturalism and the Shift to Assimilation in the Netherlands. Ethnic and Racial Studies, 30, 713-740. https://doi.org/10.1080/01419870701491770

Vermeulen, H., \& Pennix, R. (Eds.) (2000). Immigrant Integration: The Dutch Case. Amsterdam: Het Spinhuis.

Vertovec, S. (1996). Multiculturalism, Culturalism and Public Incorporation. Ethnic and Racial Studies, 1, 49-69. https://doi.org/10.1080/01419870.1996.9993898

Vertovec, S. (2007). Super-Diversity and Its Implications. Ethnic and Racial Studies, 30, 1024-1054. https://doi.org/10.1080/01419870701599465

Vertovec, S. (2010). Towards Post-Multiculturalism? Changing Communities, Conditions and Contexts of Diversity. International Social Science Journal, 61, 83-96. https://doi.org/10.1111/j.1468-2451.2010.01749.x

Walzer, M. (1999). The Exclusions of Liberal Theory. Frankfurt: Fischer.

Wieviorka, M. (1998a). Le multiculturalisme est-il la response? Cahiers Internationaux de sociologie, 2, 233-260. https://www.jstor.org/stable/40690785

Wieviorka, M. (1998b). Is Multiculturalism the Solution? Ethnic and Racial Studies, 21, 881-910. https://doi.org/10.1080/014198798329702

Wieviorka, M. (2001). La différence. Paris: Les Éditions Balland.

Young, I. M. (1989). Polity and Group Difference: A Critique of the Ideal of Universal Citizenship. Ethics, 99, 250-274. https://doi.org/10.1086/293065

Young, I. M. (1990). Justice and the Politics of Difference. Princeton: Princeton University Press.

Zamagni, S. (2002). Migrazioni, multiculturalità e politiche dell'identità. In C. Vigna, \& S. Zamagni (Eds.), Multiculturalismo e Identità (pp. 221-263). Milano: Vita e Pensiero.

Zapata-Barrero, R. (2016). Theorising Intercultural Citizenship. In N. Meer, T. Modood, \& R. Zapata-Barrero (Eds.), Multiculturalism and Interculturalism: Debating the Dividing Lines (pp. 53-76). Edinburgh: Edinburgh University Press.

Zapata-Barrero, R. (2017). Interculturalism in the Post-Multicultural Debate: A Defence. Comparative Migration Studies, 5, 14. https://doi.org/10.1186/s40878-017-0057-Z 